\title{
PERGESERAN ORIENTASI ADOPSI ANAK DI KALANGAN PNS
}

\section{(STUDI DI LOMBOK TENGAH)}

\author{
Tuti Harwati ${ }^{1}$ \\ tuti_harwati@uinmataram.ac.id
}

\begin{abstract}
Abstrak:Dewasa ini, muncul fenomena menarik bahwa tujuan mengangkat anak, terutama oleh seseorang yang memiliki latar belakang sebagai Pegawai Negeri Sipil (PNS) tidak lagi semata-mata hanya karena ingin memiliki anak atau membantu si anak (angkat), melainkan lebih disebabkan karena adanya tunjangan PNS, yaitu anak angkat adalah termasuk yang mendapatkan tunjangan sebesar $2 \%$ dari gaji pokok PNS (vide pasal 16 ayat 2 PP No. 7 Tahun. 1977 Tentang Gaji Pegawai Negeri Sipil). Indikasi ini semakin terlihat ketika anak yang diangkat merupakan anak dari kerabat dekat calon orang tua asuh, seperti keponakan, cucu dan sebagainya. Padahal, tanpa mengangkat anak dari keluarga dekatnya seseorang tidak akan terhalang untuk memberikan kasih sayang, nafkah, dan bantuan pendidikan misalnya, sehingga patut diduga ada motif lain dalam kasus pengangkatan anak yang dilakukan oleh seorang PNS. Dari hasil penelitian terungkap bahwa:
\end{abstract}

Pertama: Motif dan tujuan adopsi anak yang dilakukan oleh Pegawai Negeri Sipil (PNS) di Kabupaten Lombok Tengah dapat dibagi ke dalam dua bagian, yaitu motif dari calon orang tua angkat atau pengangkat dan motif dari orang tua kandung calon anak angkat. Adapun alasan dari calon orang tua angkat, antara lain karena: kesepian, tidak mempunyai keturunan dan atas dasar perasaan sosial. Sedangkan motif dari orang tua kandung calon anak angkat, yaitu: faktor ekonomi dan untuk meningkatkan kesejahteraan anak.

Kedua: Bentuk pergeseran orientasi adopsi atau pengangkatan anak yang dilakukan oleh para pegawai negeri sipil di Lombok Tengah tidak hanya dilakukan demi kesejahteraan calon anak angkat, melainkan juga demi calon orangtua angkat supaya mendapatkan tunjangan anak dalam daftar gaji.

Ketiga: Implikasi hukum terhadap pergeseran orientasi adopsi atau pengangkatan anak oleh pegawai negeri sipil di Kabupaten Lombok 
Tengah dapat dibenarkan secara legal-formal. Sebab, menurut Peraturan Pemerintah Republik Indonesia Nomor 7 Tahun 1977 tentang Peraturan Gaji Pegawai Negeri Sipil Pasal 16 ayat 2 yang memuat tunjangan anak sebesar $2 \%$ per anak dari gaji pokok. Namun demikian, tindakan tidak menjadikan keluarga, baik keponakan dan khususnya cucu sebagai anak angkat dalam kasus ini harus lebih didahulukan dalam rangka untuk mencegah dampak negatif di kalangan ahli waris yang lain, meskipun menurut peraturan yang berlaku tidak ada halangan bagi seorang kakek dan nenek untuk mengangkat cucu kandungnya sebagai anak angkat.

Kata Kunci: Adopsi Anak, Pergeseran Orientasi, Pegawai Negeri Sipil

\section{PENDAHULUAN}

Islam adalah agama rahmat li al-alamin, agama yang membawa misi universal yang tujuan utamanya adalah supaya umat manusia di seluruh dunia selamat di dunia dan akhirat di bawah panji-panji keagungan ajarannya. Sistem dan konsep yang dibawa Islam sesungguhnya padat nilai dan memberikan manfaat yang luar biasa kepada umat manusia. Konsepnya tidak hanya berguna pada masyarakat muslim tetapi dapat dinikmati oleh siapapun. Sistem Islam ini tidak mengenal batas, ruang dan waktu, tetapi selalu baik kapan dan dimana saja tanpa menghilangkan factorfaktor kekhususan masyarakat. Semakin utuh konsep itu diaplikasikan, semakin besar manfaat yang diraih.

Islam tidak hanya mengatur hubungan manusia dengan Tuhan, tetapi juga mengatur mencakup seluruh aspek kehidupan baik politik, hukum, sosial dan budaya. Diantara beberapa hukum yang telah ditetapkan oleh Allah SW'T dalam kaitannya dengan sesama manusia adalah hukum pengangkatan anak yang berhubungan dengan hak pemeliharaan anak (badhanah). Anak-anak adalah kelompok rentan yang membutuhkan perlindungan khusus, dalam Islam disebutkan bahwa anak adalah warisan berharga dan amanah atau titipan Tuhan kepada hambaNya. Anak dalam rumah tangga atau keluarga dapat dilihat dari dua dimensi ilmiah, yaitu: pertama, anak sebagai buah alami (sunnatullah), hasil kekuatan rasa kasih sayang suami istri (Mu'asyarah bil Ma'ruf) sebagai Mawaddah dan Rahmat Allah SW'T untuk memperkuat bangunan hubungan rumah tangga yang rukun dan damai, bahagia dan sejahtera sesuai dengan nilai-nilai Islam. Kedua, anak sebagai penerus generasi, pelindung 
manakala orang tua disaat lemah dan pelanjut doa (ritual communication) mana kala orang tuanya meninggal dunia memenuhi panggilan Khalik sebagai PenciptaNya. ${ }^{2}$

Anak dalam keluarga adalah buah hati belahan jiwa. Untuk anak, orang tua bekerja memeras keringat membanting tulang. Anak merupakan harapan utama bagi sebuah mahligai perkawinan. Keberadaan anak adalah wujud keberlangsungan sebuah keluarga, keturunan dan bangsa setelah agama. Namun, anak adalah karunia Allah SWT. Tidak semua mahligai perkawinan dianugarehi keturunan, generasi penerus, hingga suami istri tutup usia. Allah SWT mengaruniai anak kepada Nabi Ibrahim yaitu Isma'il dan Ishaq pada usia senja, yang pertama di usia 99 tahun, yang terakhir 112 tahun. Itu terjadi tatkala usia senja dan harapan untuk mendapatkan keturunan sampai pada titik putus. Allah SWT berfirman melalui lisan Nabi Ibrahim, yaitu : "segala puji bagi Allah SWT yang telah menganugerahkan kepadaku di hari tua (ku) Isma'il dan Ishaq. Sesungguhnya Rabbku, benar-benar Maha Pendengar (memperkenankan) doa “(QS. Ibrahim: 39).

Keinginan untuk mempunyai anak adalah naluri manusiawi dan alami akan tetapi kadang-kadang naluri ini terbentur oleh takdir illahi, dimana kehendak mempunyai anak tidak tercapai. Akan tetapi semua kuasa ada di tangan Tuhan. Apapun yang mereka usahakan apabila Tuhan tidak menghendaki, maka keinginan merekapun tidak akan terpenuhi, hingga jalan terakhir semua usaha tidak membawa hasil, maka diambil jalan dengan pengangkatan anak.

Secara faktual diakui bahwa pengangkatan anak telah menjadi bagian dari adat kebiasaan masyarakat muslim di Indonesia dan telah merambah dalam praktek melalui lembaga peradilan agama, maka sebelum terbentuknya undang-undang yang mengatur secara khusus, pemerintah telah mengeluarkan Instruksi Presiden Nomor 1 Tahun 1991 tentang Penyebarluasan Kompilasi Hukum Islam. Definisi anak angkat dalam Kompilasi Hukum Islam jika diperbandingkan dengan definisi anak angkat dalam Undang-Undang Nomor 23 Tahun 2002 tentang Perlindungan Anak, memiliki kesamaan substansi. Pasal 1 angka 9 dinyatakan bahwa "Anak Angkat adalah anak yang haknya dialihkan dari lingkungan kekuasaan keluarga orang tua, wali yang sah, atau orang lain yang bertanggung jawab atas perawatan, pendidikan, dan membesarkan anak tersebut, ke dalam lingkungan keluarga orang tua angkatnya berdasarkan putusan atau penetapan pengadilan".

Hal penting yang perlu digarisbawahi bahwa pengangkatan anak harus dilakukan dengan proses hukum dengan produk penetapan pengadilan. Jika hukum berfungsi sebagai penjaga ketertiban dan sebagai rekayasa sosial, maka pengangkatan anak

2 Mohammad Thalib, Analisa Wanita Dalam Bimbingan Islam, (Surabaya: Al-Ikhlas, 1987), hlm. 168. 
yang harus dilakukan melalui penetapan pengadilan tersebut merupakan kemajuan ke arah penertiban praktik hukum pengangkatan anak yang hidup di tengahtengah masyarakat, agar peristiwa pengangkatan anak itu di kemudian hari memiliki kepastian hukum baik bagi anak angkat maupun bagi orang tua angkat. Praktik pengangkatan anak yang dilakukan melalui pengadilan tersebut, telah berkembang baik di lingkungan Pengadilan Negeri maupun dalam lingkungan Pengadilan Agama bagi mereka yang beragama Islam.

Adapun dalam kaitannya dengan motivasi atau tujuan melakukan pengangkatan anak adalah supaya anak yang diangkat mendapatkan pengasuhan, pendidikan, pemeliharaan dan kasih sayang layaknya anak kandung sendiri oleh orang tua angkatnya. Dalam perspektif hukum Islam dalam pengangkatan anak tidak boleh memutuskan hubungan nasab antara anak yang diangkat dengan orang tua kandungnya sendiri. Anak tidak diakui untuk dijadikan sebagai dasar dan sebab mewarisi, karena prinsip pokok dalam kewarisan adalah hubungan darah atau arham. ${ }^{3}$

Atas dasar itulah, menurut hukum Islam, tujuan utama pengangkatan anak adalah demi kepentingan anak itu sendiri, dengan tidak memutuskan hubungan nasab dengan orang tua kandungnya serta calon orang tua angkat seagama dengan anak yang bersangkutan atau seagama dengan orang tua kandung anak yang bersangkutan, dalam hal anak tersebut masih kecil, dan hal-hal tersebut telah diatur dalam beberapa ketentuan perundang-undangan dalam pasal 171 huruf (h) KHI, "anak angkat adalah anak yang dalam hal pemeliharaan untuk hidupnya sehari-hari, biaya pendidikan dan sebagainya beralih tanggung jawabnya dari orang tua asal kepada orang tua angkatnya berdasarkan putusan pengadilan". Hal ini juga ditegaskan dalam pasal 39 ayat (1) UU No. 23 Tahun. 2002 tentang Perlindungan Anak, ayat (1) "pengangkatan anak hanya dapat dilakukan untuk kepentingan anak yang terbaik bagi anak dan dilakukan berdasarkan adat kebiasaan setempat dan ketentuan peraturan perundangundangan." Ayat (2) "pengangkatan anak disini tidak memutuskan hubungan darah antara anak yang diangkat dan orang tua kandungnya."

Namun demikian, dewasa ini, muncul fenomena menarik bahwa tujuan mengangkat anak, terutama oleh seseorang yang memiliki latar belakang sebagai Pegawai Negeri Sipil (PNS) tidak lagi semata-mata hanya karena ingin memiliki anak atau membantu si anak (angkat), melainkan lebih disebabkan karena adanya tunjangan PNS, yaitu anak angkat adalah termasuk yang mendapatkan tunjangan sebesar 2\% dari gaji pokok PNS (vide pasal 16 ayat 2 PP No. 7 Tahun. 1977 Tentang Gaji Pegawai Negeri Sipil). Indikasi ini semakin terlihat ketika anak yang diangkat merupakan anak dari kerabat dekat calon orang tua asuh, seperti keponakan, cucu dan

3 Hilman Hadikusuma, Hukum Waris Adat, (Bandung: Alumni, 1983), hlm. 88. 
sebagainya. Padahal, tanpa mengangkat anak dari keluarga dekatnya seseorang tidak akan terhalang untuk memberikan kasih sayang, nafkah, dan bantuan pendidikan misalnya, sehingga patut diduga ada motif lain dalam kasus pengangkatan anak yang dilakukan oleh seorang PNS.

Pergeseran orientasi pengangkatan anak oleh PNS inilah yang akan peneliti kaji lebih seksama dan mendalam secara ilmiah dengan mengambil latar penelitian di Kabupaten Lombok Tengah. Penelitian ini menjadi sangat urgen, sebab dari sisi hukum, mengangkat anak dari keluarga dekat dapat dianggap tidak berdasarkan hukum sehingga permohonan pengangkatan anak oleh seorang yang memiliki latar belakang PNS merupakan permohonan yang kabur (obscuur libe), dan tidak dapat diteriama/Niet Onvankelijk Verklaart (NO). Hal ini disebabkan karena pengangkatan anak disini adalah oleh kakek-nenek atau paman-bibinya sendiri misalnya akan sangat berpengaruh pada sistem kewarisan sebagaimana dimaksud pasal $209 \mathrm{KHI}$ di kemudian hari, dimana anak angkat mendapatkan hak waris melalui wasiyat wajibah maksimal sepertiga (1/3) bagian dari harta warisan orang tua angkatnya. Dengan demikian, hal tersebut akan mengurangi hak waris anak kandung orangtua angkat, padahal anak yang akan diangkat tersebut tanpa dijadikan anak angkat pun tidak menghalangi hubungan kasih sayang, tidak menghalangi pemberian bantuan pemeliharaan, pengasuhan, pendidikan dan hal-hal lain sebagaimana disinggung sebelumnya. Apabila permohonan pengangkatan anak tersebut dikabulkan oleh pengadilan, justru akan menimbulkan permasalahan (mafsadah) di kemudian hari, sehingga tidak memenuhi asas manfaat, kepastian hukum dan rasa keadilan, berdasarkan pertimbangan tersebut maka permohonan tidak dapat diterima.

\section{Motivasi dan Pergeseran Orientasi Adopsi Anak di Kalangan PNS Kabupaten Lombok Tengah}

1. Motif dan tujuan adopsi anak

Pada dasarnya, secara umum, dalam rangka pelaksanaan perlindungan anak, sangat penting melihat alasan/motivasi pengangkatan anak sehingga sangat perlu diperhatikan, dan harus dipastikan dilakukan demi kepentingan yang terbaik untuk anak. Motivasi merupakan suatu pengertian yang melingkupi penggerak, alasanalasan, dorongan yang menyebabkan seseorang berbuat sesuatu. Misalnya seseorang menjadi anggota perkumpulan maka motivasinya antara lain ingin sesuatu yang baru bersama anggota perkumpulannya tersebut. ${ }^{4}$

4 W.A. Gerungan, Psikologi Sosial Suatu Ringkasan, (Jakarta: Cet. V Eresco, 1977), hlm. 142. 
Dalam kaitannya dengan pengangkatan anak berarti dengan adanya alasanalasan atau motivasi atau dorongan yang melatarbelakangi seseorang melakukan perbuatan hukum mengangkat anak. Apabila melihat pada alasan/motivasi serta tujuan pengangkatan anak, maka akan banyak sekali ragamnya. Djaja S. Meliala misalnya membagi secara detail alasan terpenting seseorang melakukan pengangkatan anak, yaitu antara lain:

1. Rasa belas kasihan terhadap anak terlantar atau anak yang orang tuanya tidak mampu memeliharanya.

2. Tidak mempunyai anak dan ingin mempunyai anak untuk menjaga dan memeliharanya di hari tua.

3. Adanya kepercayaan bahwa dengan adanya anak di rumah maka akan dapat mempunyai anak sendiri.

4. Untuk mendapatkan teman bagi anaknya yang sudah ada.

5. Untuk menambah atau mendapatkan tenaga kerja.

6. Untuk mempertahankan ikatan perkawinan / kebahagiaan keluarga. ${ }^{5}$

Ada beberapa alternatif yang digunakan sebagai dasar atau alasandilaksanakan suatu pengangkatan anak antara lain:

(1) Dilihat dari sisi adoptant, karena ada alasan sebagai berikut:

a. Keinginan mempunyai keturunan atau anak;

b. Keinginan untuk mendapat teman bagi dirinya sendiri atau anaknya;

c. Kemauan untuk menyalurkan rasa belas kasihan terhadap anak orang lain yang membutuhkan;

d. Adanya ketentuan hukum yang memberi peluang untuk melakukan suatu pengangkatan anak;

e. Adanya pihak yang menganjurkan pelaksanaan pengangkatan anak untuk kepentingan pihak tertentu.

(2) Dilihat dari sisi orang tua anak, karena alasan sebagai berikut:

a. Perasaan tidak mampu untuk membesarkan anaknya sendiri;

b. Kesempatan untuk meringankan beban sebagai orang tua karena ada pihak yang ingin mengangkat anaknya;

c. Imbalan-imbalan yang dijanjikan dalam hal penyerahan anak;

d. Saran-saran dan nasihat pihak keluarga atau orang lain;

e. Keinginan agar anaknya hidupnya lebih baik dari orang tua kandungnya;

5 Djaja S.Meliala, Pengangkatan Anake (Adopsi) di Indonesia, (Bandung: Tarsito, 1982), hlm. 3. 
f. Ingin agar anaknya terjamin materiil selanjutnya;

g. Masih mempunyai anak beberapa lagi;

h. Tidak mempunyai rasa tanggung jawab untuk membesarkan anaknya sendiri;

i. Keinginan melepaskan anaknya karena rasa malu sebagai akibat hubungan tidak sah;

j. Keinginan melepaskan anaknya karena rasa malu mempunyai anak yang tidak sempurna fisiknya. ${ }^{6}$

Dalam kaitannya dengan motivasi pengangkatan anak, menurut Datuk Usman ada berbagai motif dari pengangkatan anak ini antara lain:

1. Tidak mempunyai anak (untuk melangsungkan keturunan).

2. Agar ada orang yang mengurus apabila sudah tua nantinya.

3. Untuk melanjutkan dan memelihara harta benda.

4. Untuk pemeliharaan berkala.

5. Untuk memasukkan seseorang kedalam masyarakat hukum.

6. Mengangkat derajat seseorang kepada kedudukan yang lebih tinggi.

7. Karena belas kasihan kepada anak yatim piatu atau orang tuanya tidak mampu.

8. Karena anak-anaknya yang ada hanya laki-laki/perempuan saja, sedangkan ia menginginkan sebaliknya.

9. Sebagai pemancing bagi yang tidak mempunyai anak untuk dapat mempunyai anak kandung.

10. Untuk menambah tenaga dalam keluarga.

11. Untuk mempererat hubungan kekeluargaan.

12. Anak dahulu sering penyakitan atau meninggal, maka anak yang baru lahir diserahkan kepada keluarga lain untuk diadopsi agar anak selalu sehat dan panjang umur.

13. Mengangkat anak tiri menjadi anak kandung (di Rejang disebut Mulang Jurai, di Kalimantan disebut Ngukup).

14. Mengangkat kedudukan anak perempuan. Biasanya anak perempuan sendiri dirubah kedudukannya serupa dengan kedudukan anak laki-laki, misalnya di Bali disebut dengan Anak Sentana, di Karo disebut Ilakiken. Berbeda

6 Irma Setyowati Soemitro, Aspek Hukum Perlindungan Anak, (Jakarta: Bumi Aksara, 1990), hlm.38. 
dengan di Bali Anak Sentana adalah untuk pelanjut keturunan dan menjadi ahli waris, di Karo hanya terbatas dalam penerimaan warisan saja.

15. Mengangkat derajat seorang anak (laki-laki) dari seorang isteri yang kedudukannya rendah (selir) menjadi anak dari istri yang lebih tinggi kedudukannya, misalnya di Bali dan Lampung.

16. Mengangkat menantu menjadi ahli waris, yaitu mengangkat seorang laki-laki dan dimasukkan kedalam kerabat mertua laki-lakinya, misalnya di Lampung dan di perbatasan Minangkabau dan Tapanuli.

17. Memasukkan seorang anak dari klan ibu ke klan bapak, misalnya di Rejang.

18. Mendapatkan teman bagi anaknya.

19. Untuk mempertahankan ikatan perkawinan/kebahagiaan keluarga

20. Untuk dinikahkan dengan anak adoptan. ${ }^{7}$

Secara umum pengangkatan anak menurut hukum adalah pengalihan anak kepada orang tua angkat dari orang tua kandung secara keseluruhan dan dilakukan menurut adat setempat agar sah. Jadi orang tua kandung sudah lepas tangan terhadap anak itu, dan tanggung jawab beralih kepada orang yang mengangkatnya.

Konsep pengangkatan anak dalam hukum Islam tidak mengenal pengangkatan anak dalam arti menjadi anak kandung secara mutlak, sedang yang ada hanya diperbolehkan atau suruhan dengan motivasi untuk memelihara dengan tujuan memperlakukan anak dalam segi kecintaan dan kasih sayang, pemberian nafkah, pendidikan atau pelayanan dalam segala kebutuhan yang bukan memperlakukan sebagai anak kandung (nasab). Sedangkan mendidik anak, melayani, dan memenuhi segala kebutuhan yang dibutuhkan seorang anak adalah bagian dari badhanah yang sangat dianjurkan oleh Islam. Perlu ditegaskan, bahwa tujuan pengangkatan anak adalah untuk kesejahteraan anak, bukan untuk kepentingan calon orang tua angkat. Inilah konsep Islam yang sejalan dengan Undang-Undang Nomor 23 Tahun 2002 tentang Perlindungan Anak. Oleh karena dalam syariat Islam dan hukum Islam tidak diberikan hak waris kepada anak angkat ataupun orang tua angkat maka Kompilasi Hukum Islam (KHI) memberikan wasiat wajibah maksimal 1/3 bahagian, itupun dengan mengajukan permohonan dan dengan putusan/penetapan dari Mahkamah Syar'iyah ataupun Pengadilan Agama.

Mulai dari sini peneliti akan menganalisis motif dan alasan para PNS mengangkat anak. Berdasarkan data kasus per kasus tentang adopsi yang dilakukan oleh Pegawai

7 Datuk Usman, Diktat Hukum Adat, Dipakai dalam Lingkungan Sendiri pada FH-USU, Medan, tanpa tahun, hlm. 89-92. 
Negeri Sipil di Kabupaten Lombok Tengah sebagaimana paparan data yang telah disampaikan pada bab sebelumnya, ada beberapa factorpenyebabpengajuan perkara permohonan pengangkatan anak danpengangkatan anak di Pengadilan Agama Praya. Faktor-faktortersebut dapat dibagi kedalam dua bagian, yaitu faktor penyebab dari calon orang tua angkat atau pengangkat dan faktor penyebab dari orang tua kandung calon anak angkat.

Beberapa faktor penyebab dari calon orang tua angkat, antara lain:

a. Kesepian

Dari semua kasus adopsi yang dilakukan oleh Pegawai Negeri Sipil di Kabupaten Lombok Tengah, kesepian merupakan faktor penyebab utama dari calon orang tua angkat untuk mengajukan permohonan pengangkatan anak. Namun demikian, kesepian yang dimaksud bukan karena tidak mempunyai keturunan atau tidak mempunyai anak kandung. Faktor kesepian ini biasanya disebabkan karena anakkandung sudah berumah tangga sehingga tidak tinggal serumah lagi dengan orang tua. Pada akhirnya orang tua merasa kesepian di rumah tanpa adanya penghibur hati yang menghiasi hari-hari tua.

b. Tidak Mempunyai Keturunan

Tidak mempunyai keturunan atau yang lazim disebut dengan mandul merupakan salah satu faktor penyebab seseorang mengajukan untuk mengangkat atau mengangkat anak, dan hal semacam ini sering kita temukan di tengah-tengah masyarakat. Pada umumnya orang yang mengajukan permohonan pengangkatan atau pengangkatan anak anak memiliki tingkat perekonomian memadai, sehingga besar kemungkinan bagi anak angkat atau anak angkat untuk mendapatkan penghidupan yang layak dan mendapatkan kesejahteraan dalam hidup. Namun demikian, dari empat kasus pengangkatan anak angkat yang peneliti temukan, hanya satu kasus yang menjadikan alasan tidak memiliki keturunan sebagai motif melakukan permohonan pengangkatan anak.

c. Berjiwa Sosial

Dengan dasar jiwa sosial yang kuat dapat mendorong seseorang untuk senantiasa membantu sesama sebagai makhluk sosial yang membutuhkan bantuan dan dukungan moril dan materil dari orang lain untuk senantiasa memperoleh hak-hak dalam hidup, seperti halnya seorang anak yang berhak atas pemeliharaan, pendidikan, sandang, pangan, dan papan. Hal tersebut menjadi salah satu motivasi seseorang untuk mengajukan permohonan pengangkatan anak atau pengangkatan anak. 
Pada dasarnya, dari empat kasus pengangkatan anak yang dilakukan oleh kalangan PNS di Kabupaten Lombok Tengah tersebut terungkap bahwa semua pelaku, dalam laporan pengakuannya, mengaku melakukan pengangkatan anak atas dasar perasaan jiwa sosial karena merasa mampu baik moril maupun spiritual untuk memelihara, mengasuh dan memenuhi kebutuhan hidup calon anak angkat, khususnya pendidikannya. Meskipun harus diakui pula secara jujur bahwa dari empat kasus pengangkatan anak yang dimohonkan ke Pengadilan Agama Praya tersebut semuanya mengambil anak angkat yang masih ada hubungan keluarga dengan calon anak angkat. Dua orang mengangkat anak saudara sendiri, yaitu keponakannya, dan dua orang lagi justru mengangkat anak dari anak pemohon atau cucu sendiri sebagai anak angkat. Ini berarti hubungan pemohon dan calon anak angkat benar-benar masih terikat hubungan kekeluargaan secara dekat. Hal ini misalnya terlihat dari Keputusan Majelis hakim yang mengabulkan permohonan dan Menyatakan sah pengangkatan anak yang dilakukan oleh Pemohon I (Baiq Haryani binti Lalu Muh. Sidik) dan Pemohon II (Lalu Samidah bin Mamiq Lusin) Desa Darek, Kecamatan Praya Barat Daya, Kabupaten Lombok Tengah terhadap anak yang bernama Letra Junita Ningrum binti Sutrisna Ramdani (perempuan, umur dua puluh tujuh bulan.

d. Sebagai Pancingan untuk Mendapat Keturunan

Ada juga orang yang dengan sengaja mengangkat atau mengangkat anak untuk menjadikan anak tersebut sebagai pancingan mendapatkan anak kandung, hal ini biasanya dilakukan oleh pasangan suami-istri yang sudah cukup lama menikah akan tetapi belum dikaruniai anak.Namun dari empat kasus yang peneliti temukan di lapangan, tidak ada pasangan atau pemohon yang menjadikan alasan "Pancingan untuk Mendapat Keturunan” sebagai motif melakukan pengangkatan anak .

Adapun beberapa Faktor Penyebab dari Orang Tua Kandung Calon Anak Angkat, antara lain:

a) Faktor Ekonomi

Faktor ekonomi merupakan faktor utama bagi orang tua untuk melepas dan melimpahkan pemeliharaan anaknya kepada keluarga, kerabat, orang lain atau lembaga sosial. Tingkat perekonomian yang rendah mengakibatkan tarap kesejahteraan hidup menjadi rendah, dan pada akhirnya banyak orang tua yang tidak mampu memenuhi hak-hak anaknya berupa perawatan, pendidikan, kesehatan dan lain sebagainya, sehingga dengan landasan tersebut orang tua dengan merasa rendah hati merelakan anaknya untuk diangkat orang lain.

Untuk alasan ini, semua orang tua kandung dari calon anak angkat yang dilakukan oleh empat pemohon ke Pengadilan Agama Praya menjadikan alasan 
ekonomi sebagai motif mengikhlaskan anak kandungnya dipelihara dan diasuh orang lain. Hal ini tidak mengherankan, sebab rata-rata orang tua kandung calon anak angkat tidak memiliki pekerjaan dan penghasilan tetap sehingga tidak mampu memenuhi tanggungjawab mereka terhadap pemeliharaan, kebutuhan dan masa depan anak kandungnya.

b) Meningkatkan Kesejahteraan Anak

Dalam rangka meningkatkan kesejahteraan anak menuju kearah perubahan yang lebih baik, bagi para orang tua yang taraf perekonomiannya pas-pasan untuk kelangsungan kehidupan keluarga, terkadang lebih memilih untuk menitipkan anaknya untuk diangkat oleh keluarga yang perekonomiannya lebih mapan, kerabat, orang lain atau lembaga demi mendapatkan penghidupan dan pendidikan yang lebih baik. Alasan ini pula yang menjadi motivasi terbesar para orang tua kandung calon anak angkat di Lombok Tengah dari empat kasus yang berhasil peneliti dapatkan. Sebab, orang lain yang akan mengangkat anak mereka sebagai anak angkat adalah pegawai negeri sipil, yang sudah memiliki gaji tetap dan penghasilan cukup bahkan lebih sebagai jaminan pememeliharaan, pemenuhan kebutuhan, kesejahteraan serta pendidikan demi masa depan anaknya di kemudian hari.

\section{Bentuk pergeseran orientasi adopsi anak di Kalangan Pegawai Negeri Sipil (PNS) di Kabupaten Lombok Tengah ${ }^{8}$}

Pengangkatan anak sudah dikenal dan berkembang sebelum kerasulan NabiMuhammad SAW. Tradisi pengangkatan anak sebenarnya jauh sebelum Islamdatang telah dikenal oleh manusia, seperti pada bangsa Yunani, Romawi, India,Bangsa Arab sebelum Islam (jahiliah). Imam al-Qurtubi (ahli tafsir klasik) menyatakan bahwa sebelum kenabian, Rasulullah SAW pernah mengangkat Zaidbin Haritsah menjadi anaknya, bahkan beliau tidak lagi memanggilnya berdasarkan nama ayahnya (Haritsah), tetapi ditukar oleh Rasulullah menjadi nama Zaid bin Muhammad. Rasulullah juga mengumumkan pengangkatan Zaid sebagai anak angkatnya di depan kaum Quraisy dan menyatakan bahwa dirinyadan Zaid saling mewarisi. ${ }^{9}$

Mengenai pengangkatan anak dalam perkembangan hukum di Indonesiaproses pengangkatan anak pada awalnya diatur berdasarkan Surat EdaranMahkamah Agung tanggal 7 April 1979 No.2 Tahun 1979 tentang Pengangkatan Anak dikatakan antara

8 Atas dasar kepentingan analisa data, maka pada bagian ini peneliti sebagian besar menyadur tulisan Maya Sari, "Pengaruh Surat Penetapan Pengadilan Atas Pengangkatan Anak Bagi Pegawai Negeri Sipil Muslim Dalam Daftar Gaji (Studi Kasus Terhadap Penetapan Nomor 21/Pdt.P/2010 di Pengadilan Agama Medan)", dalam Jurnal Fakultas Hukum Universitas Sumatera Utara, Medan, 2014. Oleh karenanya, di beberapa tempat peneliti langsung merujuk pada karya dimaksud.

9 Abdul Aziz Dahlan (et. al.), Eksiklopedi Hukum Islam, (Jakarta: Ichtiar Baru Van Hoeve, 1996), hlm. 27. 
lain bahwa:"Pengesahan Pengangkatan Anak Warga Negara Indonesia hanya dapat dilakukan dengan suatu penetapan di Pengadilan Negeri, dan tidak dibenarkan apabila pengangkatan anak tersebut dilakukan dengan akta yang dilegalisir oleh Pengadilan Negeri'. Dengan demikian, setiap kasus pengangkatan anak harus melalui Penetapan Pengadilan Negeri". ${ }^{10}$

Dengan keluarnya Undang-undang Nomor 3 Tahun 2006 tentang PengadilanAgama menyebutkan ada penambahan dalam kewenangan Pengadilan Agamatentang penetapan pengangkatan anak berdasarkan hukum Islam. ${ }^{11}$ Menurut Hukum Islam, anak angkat tidak dapat diakui untuk dapat dijadikan dasar dansebab mewarisi, karena prinsip pokok dalam kewarisan Islam adalah hubungan darah atau nasab/keturunan. ${ }^{12}$ Dengan kata lain bahwa peristiwa pegangkatan anak menurut hukum kewarisan Islam, tidak membawa pengaruh hukum terhadap status anak angkat, yakni bila bukan merupakan anak sendiri, tidak dapat mewarisi dari orang yang setelah mengangkat anak tersebut.

Sebagaimana telah ditegaskan sebelumnya di awal, motif atau alasan pengangkatan anak di Indonesia sangat beragama, antara lain adalah: ${ }^{13}$

1. Ingin mempunyai keturunan

2. Ingin mempunyai teman untuk dirinya sendiri atau untuk anaknya karena kesepian;

3. Ingin mewujudkan rasa sosial, belas kasihannya terhadap orang lain, bangsa lain yang dalam kesulitan hidup sesuai dengan kemampuannya;

4. Adanya peraturan perundang-undangan yang memungkinkan pelaksanaan pengangkatan anak;

5. Adanya orang-orang tertentu yang menganjurkan pengangkatan anakuntuk kepentingan pihak tertentu.

Mengangkat anak merupakan suatu perbuatan hukum, oleh kerena ituperbuatan tersebut mempunyai akibat hukum. Salah satu akibat hukum dari peristiwa pengangkatan anak adalah mengenai status anak angkat tersebut sebagai ahli waris orang tua angkatnya. Status demikian inilah yang sering menimbulkan permasalahan di dalam keluarga. Persoalan yang sering muncul dalam peristiwa gugat menggugat itu biasanya mengenai sah atau tidaknya pengangkatan anaktersebut, serta kedudukan anak angkat itu sebagai ahli waris dari orang tuaangkatnya.

10 Muderis Zaini, Adopsi Suatu Tinjanan Dari Tiga Sistem Hukum, (Jakarta: Sinar Grafika, 1995), hlm. 112.

11 Musthofa Sy., Pengangkatan Anak: Kewenangan Pengadilan Agama, (Jakarta: Kencana, 2008), hlm 62.

12 Ibid, hlm. 78.

13 Shanti Dellyana, Wanita dan Anak Di Mata Hukum, (Yogyakarta: Liberty, 1988), hlm. 29. 
Haditono mengutip pendapat Sumadi Suryabrata, menyatakan bahwa:Anak merupakan mahluk yang membutuhkan pemeliharaan, kasihsayang dan tempat bagi perkembangannya. Selain itu, anak merupakanbagian dari keluarga, dan keluarga memberi kesempatan bagi anakuntuk belajar tingkah laku yang penting untuk perkembangan yangcukup baik dalam kehidupan bersama. ${ }^{14}$

Pengertian di atas menjelaskan bahwa anak merupakan generasi mudapenerus cita-cita bangsa dan merupakan sumber daya manusia bagi pembangunannasional. Anak dalam pemaknaan yang umum mendapat perhatian baik dalambidang ilmu pengetahuan, agama, hukum, dan sosiologi yang menjadikanpengertian anak semakin aktual dalam lingkungan sosial.

Kedudukan anak dalam lingkungan hukum sebagai subjek hukum, ditentukandari bentuk sistem hukum terhadap anak sebagai kelompok masyarakat yangberada di dalam status hukum dan tergolong tidak mampu atau di bawah umur.Maksud tidak mampu karena kedudukan akal dan pertumbuhan fisik yang sedangberkembang dalam diri anak yang bersangkutan. Meletakkan anak sebagai subjekhukum yang lahir dari proses sosialisasi berbagai nilai ke dalam peristiwa hukumsecara substansial meliputi peristiwa hukum pidana maupun hubungan kontrakyang berada dalam lingkup hukum perdata menjadi mata rantai yang tidak dapatdipisahkan. ${ }^{15}$

Sebagaimana peneliti sampaikan dalam bab-bab awal kerangka teori penelitian ini, pengangkatan anak di Indonesia dilihat dari sejarahnya diurut dari Staatsblad1917 Nomor 129, hukum adat, perundang-undangan dan berdasarkan hukumIslam.

Menurut Staatsblad 1917 Nomor 129, misalnya, hukum keluarga adat golongan Tionghoa menganut garis keturunan laki-laki(patrilinel), karena itu nama keluarga (she atau fam, seperti Tan, Oei, Lim,danlain-lain) diturunkan melalui keturunan laki-laki. Apabila tidak ada keturunanlaki-laki untuk meneruskan nama keluarga, maka mereka akan mengangkat anaklaki-laki dari keluarga lain. Oleh karena itu, asas pengangkatan anak hanya bisadilakukan seorang laki-laki Tionghoa wajib mengusahakan agar cabangkeluarganya tidak punah dan ada keturunan yang melanjutkan merawat abuleluhur. $^{16}$

Selanjutnya, menurut Hukum Adat, kukum kekeluargaan adat memandang bahwa keturunan adalah ketunggalanleluhur, artinya dua orang atau lebih yang mempunyai hubungan darah dengantunggal leluhur. Akibathukum yang berhubungan dengan ketunggalan leluhurbervariasi di masing-masing daerah. Ada satu pandangan

14 Sumadi Suryabrata, Pengembangan Alat Ukur Psikologis, (Yogyakarta: Andi, 2000), hlm. 3.

15 Maulana Hasan Wadong, Pengantar Advokasi dan Hukum Perlindungan Anak, (Jakarta: Grasindo, 2000), hlm. 3 .

16 Ibid. 
pokok yang sama bahwaketurunan merupakan unsur yang hakiki serta mutlak bagi suatu suku, ataukerabat yang menginginkan dirinya tidak punah dan menghendaki supaya adagenerasi penerusnya. Apabila suatu suku atau kerabat yang khawatir akanmenghadapi kepunahan pada umumnya melakukan pengangkatan anak. ${ }^{17}$

Di sisi lain, menurut Perundang-undangan Republik IndonesiaUndang-undang yang mengatur pengangkatan anak di Indonesia yang dibuatsecara lengkap dan tuntas masih belum ada. Dalam sejarah perundang-undanganyang berkaitan, pengaturan pengangkatan anak sempat masuk dalam rancanganundang-undang, yaitu dalam Rancangan Undang-Undang (RUU) tentangperkawinan dan Rancangan UndangUndang (RUU) Tentang Peradilan Anak. ${ }^{18}$

Sementara itu, berdasarkan Hukum Islam, mengangkat anak saat ini adalah merupakan hal yang wajar dilakukan bagisetiap orang. Baik bagi mereka yang belum dikaruniai keturunan ataupun yangtelah dikaruniai keturunan. Karena hali ini diperbolehkan oleh Undang-undangdan telah diatur dalam ketentuan-ketentuan hukum. Pengangkatan anak telahdilakukan dari zaman dahulu, bahkan sebelum Indonesia merdeka. Walaupunpada masa sekarang ini pelaksanaan pengangkatan anak telah jauh berkembang.Hal ini dapat dilihat dari tujuan pelaksanaan pengangkatan anak yang sudahberkembang dari tujuan semula diadakannya pengangkatan anak. Namun biladiperhatikan dari segi apapun juga, pada dasarnya pengangkatan anak mempunyaitujuan yang sama yaitu untuk memperoleh keturunan.

Berkaitan dengan kenyataan ini, proses pengangkatan anak yang menuju kearah suatu bisnis jasa komersial merupakan hal yang amat penting untuk dicegahkarena hal ini bertentangan dengan asas dan tujuan pengangkatan anak. Padadasarnya, pengangkatan anak tidak dapat diterima menurut asas-asas perlindungananak. Pelaksanaan pengangkatan anak dianggap tidak rasional positif, tidak dapatdipertanggungjawabkan, bertentangan dengan asas perlindungan anak, sertakurang bermanfaat bagi anak yang bersangkutan.

Pengangkatan anak dilakukan melalui Dinas Sosial dan diatur dalamKetentuan Umum angka 6 Keputusan Menteri Sosial Nomor40/HUK/KEP/IX/1980 tentang Organisasi Sosial yang menyatakan bahwa"Organisasi sosial/lembaga pelayanan sosial adalah lembaga kesejahteraan sosialyang berbadan hukum yang menangani pengangkatan anak yang ditunjuk olehDinas Sosial melalui Surat Keputusan Menteri Sosial sebagai penyelenggarapengangkatan anak". ${ }^{19}$

17 Bushar Muhammad, Pokok - pokok Hukum Adat, (Jakarta: Pradnya Paramita, 2006), hlm. 3.

18 Musthofa Sy, Pengangkatan Anak ..., hlm. 30.

19 Keputusan Menteri Sosial Nomor 40/HUK/KEP/IX/1980 tentang Organisasi Sosial 
Untuk menerapkan kewenangan absolut Pengadilan Agama dalammemberikan penetapan pengangkatan anak berdasarkan hukum Islam perludiketahui terlebih dahulu dasar hukum penerapannya. Peraturan perundang-undangan belum memadai dalam mengatur penerapan kewenangan pengangkatananak berdasar hukum Islam tersebut.

Sesuai ketentuan Pasal 54 Undang-UndangRI Nomor 7 Tahun 1989 jo Undang-Undang RI Nomor 3 Tahun 2006, makadalam hal ini hukum acara yang berlaku adalah hukum acara perdata yang berlakupada pengadilan dalam lingkungan peradilan umum. Kewenangan PengadilanAgama itu juga diatur pada Pasal 49 Ayat (1) Undang-Undang Nomor 7 Tahun1989 Tentang Pengadilan Agama yang menegaskan bahwa Pengadilan Agamabertugas dan berwenang memeriksa, memutus, dan menyelesaikan perkara-perkara di tingkat pertama antara orang-orang yang beragama Islam. Akidah Islamyang melekat dalam diri seseorang menjadi patokan kewenangan PengadilanAgama Terhadap suatu perkara. ${ }^{20}$

Lembaga pengangkatan anak sudah lazim dilakukan oleh masyarakat muslimIndonesia. Kehadiran Kompilasi Hukum Islam yang merupakan himpunan kaidah-kaidah Islam yang disusun secara sistematis dan lengkap mengakui eksistensilembaga pengangkatan anak tersebut dengan mengaturnya dalam ketentuan Pasal171 huruf (h) jo Pasal 209. Pasal-pasal tersebut memberikan batasan pengertiananak angkat dan akibat hukum terjadinya hubungan wasiat wajibah anatara anakangkat dengan orang tua angkatnya. Kompilasi Hukum Islam ini menjadi sumberhukum Islam bagi masyarakat muslim Indonesia yang melakukan perbuatanhukum pengangkatan anak dan menjadi pedoman hukum materiil bagi pegadilanagama dalam mengadili perkara pengangkatan anak. ${ }^{21}$

Pengangkatan anak melibatkan peran pengadilan diatur dalam Pasal 9 Ayat(1) Staatsblad 1917 Nomor 129. Pengadilan mempunyai wewenang untukmemberi izin pengangkatan anak bagi janda cerai mati apabila izin dari keluargamendiang suaminya tidak diperoleh. Izin pengadilan itu harus disebutkan dalamakta pengangkatan anak. Pengangkatan anak golongan Tionghoa hanya untuk laki-laki sehinggamenutup kemungkian peluang pengangkatan anak perempuan melalui notaris.Keinginan warga Negara Indonesia keturunan Tionghoa untuk melakukanpengangkatan anak terhadap anak perempuan tidak tertampung oleh lembagatersebut dan notaris menolak terhadap pengangkatan anak yang demikian.

Demikian pula pengangkatan yang akan dilakukan oleh calon orang tua angkatyang belum menikah. Untuk bisa melakukan pengangkatan anak yang

20 Maya Sari, "Pengaruh Surat Penetapan Pengadilan..., hlm. 8.

21 Ibid., hlm. 9. 
demikianitu harus ditempuh melalui putusan pengadilan.Dalam perkembangannya, permohonan pengangkatan anak melaluipengadilan semakin banyak. Semula hanya dikenal pengangkatan anak menurut Staatsblad 1917 nomor 129 dan hukum adat, namun kemudian berdasarkanPeraturan Pemerintah Republik Indonesia Nomor 7 Tahun 1977 tentang PeraturanGaji Pegawai NegeriSipil memungkinkan pengangkatan anak untuk mendapatkantunjangan anak. Selain itu berdasarkan Pasal 2 UndangUndang Nomor 62 Tahun1958 banyak terjadi pengangkatan anak warga Negara asing yang belum berumur5 (lima) tahun oleh warga Negara Indonesia. ${ }^{22}$

Oleh karena adanya Peraturan Pemerintah Republik Indonesia Nomor 7 Tahun 1977 tentang PeraturanGaji Pegawai Negeri Sipil memungkinkan pengangkatan anak untuk mendapatkan tunjangan anak. Terdapat beberapa hal yang dapat dijelaskan disini, ${ }^{23}$ yaitu:

1. Pertama, pengajuan pengangkatan anak bagi Pegawai Negeri Sipil muslim di Pengadilan Agama pertama pengajuan permohonan oleh yang bersangkutan yang dalam hal ini dilengkapi dengan surat pemohonan, slip gaji pemohon, buku nikah dan kartu tanda penduduk pemohon, kedua, pembayaran panjar biaya perkara, ketiga, pemohon melakukan pendaftaran perkara permohonan pengangkatan anak, keempat, penunjukan majelis hakim dan penetapan hari sidang, kelima, dalam tempo satu minggu dilakukan pemanggilan terhadap para pemohon dan sidang dilaksanakan selambat-lambatnya 2 minggu setelah pendaftaran permohonan dilakukan di Pengadilan Agama, dan kemudian setelah Penetapan dikeluarkan oleh Pengadilan Agama selanjutnya didaftarkan ke Kantor Catatan Sipil.

2. Kedua, Pengadilan Agama dalam hal pengangkatan anak sangat berwenang untuk memberikan ketetapan berupa Penetapan Pengadilan yang dimohonkan oleh Pegawai Negeri Sipil muslim yang ingin melakukan pengangkatan anak untuk kepentingan daftar gaji sesuai dengan yang diinginkan Undang-undangNomor 3 tahun 2006.

3. Ketiga, Akibat hukum dari surat penetapan Pengadilan Agama atas anak angkat bagi pegawai negeri sipil muslim adalah sahnya permohonan pengangkatan anak. Penetapan hakim atas permohonan anak angkat menimbulkan kewajiban orang tua guna menjamin terpenuhinya kewajiban orang tua angkat untuk memenuhi kewajibannya dan bagi kalangan pegawai negeri sipil adanya penetapan ini juga menjadi dasar untuk memperoleh sumber pembiayaan bagi kehidupan anak angkat dengan mana Surat Penetapan Pengadilan Agama tentang pengangkatan anak merupakan salah satu persyaratan yang harus dipenuhi dalam pengajuan

22 Sudikno Mertokusumo, Hukum Acara Perdata Indonesia, (Yogyakarta: Liberty , 1988), hlm. 36-37.

23 Maya Sari, "Pengaruh Surat Penetapan Pengadilan..., hlm. 10. 
usulan untuk mendaftarkan anak angkat dalam daftar gaji pegawai negeri sipil muslim tanpa harus melalui Pengadilan Negeri lagi.

Dengan demikian, dari penjelasan Maya Sari di atas, dapat dipahami bahwa dengan dikeluarkannya Peraturan Pemerintah Republik Indonesia Nomor 7 Tahun 1977 tentang PeraturanGaji Pegawai Negeri Sipil akan sangat memungkinkan terjadinya pergeseran orientasi pengangkatan anak oleh Pegawai Negeri Sipil yakni dalam rangka untuk mendapatkantunjangan anak. Terlepas dari berbagai macam alasan tertulis yang bersifat formal sebagaimana yang disampaikan dalam surat permohonan pengangkatan anak oleh para pegawai negeri sipil di Lombok Tengah, khususnya ke Pengadilan Agama Praya, kiranya besar kemungkinan para pegawai negeri sipil yang mengajukan permohonanpengangkatan anak untuk mendapatkan Surat Penetapan dari Pengadilan Agamauntukmemperoleh tunjangan anak dalam daftar gaji. Selain itu, dari adanya fakta bahwa calon anak angkat semuanya masih memiliki hubungan kekeluargaan dengan calon orang tua angkat yang bersangkutan, entah cucu (anaknya anak PNS calon orang tua angkat) atau keponakan (anak saudaraPNS calon orang tua angkat).

Dengan demikian, orientasi pelaksanaan adopsi atau pengangkatan anak yang dilakukan oleh para pegawai negeri sipil di Lombok Tengah tidak hanya dilakukan demi kesejahteraan calon anak angkat, melainkan juga demi calon orangtua angkat supaya mendapatkan tunjangan anak dalam daftar gaji. Namun demikian, meskipun telah terjadi pergeseran orientasi pengangkatan anak oleh pegawai negeri sipil, namun hal ini dapat dibenarkan secara legal-formal. Sebab, menurut Peraturan Pemerintah Republik Indonesia Nomor 7 Tahun 1977 tentang Peraturan Gaji Pegawai Negeri SipilPasal 16 ayat 2 yang memuat tunjangan anak, yaitu bahwa "Yang dimaksud dengan tunjangan anak adalah tunjangan yang diberikan kepada pegawai negeri yang mempunyai anak (anak kandung, anak tiri dan anak angkat) dengan ketentuan:belum melampaui batas usia 21 tahun; tidak atau belum pernah menikah; tidak mempunyai penghasilan sendiri; besarnya tunjangan anak adalah $2 \%$ per anak dari gaji pokok; batas usia anak seperti tersebut diatas dapat diperpanjang dari usia 21 tahun sampai usia 25 tahun, apabila anak tersebut masih bersekolah. ${ }^{24}$

\section{Implikasi Hukum terhadap Pergeseran Orientasi Adopsi Anak yang Dilakukan oleh Pegawai Negeri Sipil (PNS) di Kabupaten Lombok Tengah}

Jika pada analisis sebelumnya di atas ditegaskan bahwa orientasi pelaksanaan adopsi atau pengangkatan anak yang dilakukan oleh para pegawai negeri sipil di

24 Peraturan Pemerintah Republik Indonesia Nomor 7 Tahun 1977 tentang Peraturan Gaji Pegawai Negeri Sipil 
Lombok Tengah tidak hanya dilakukan demi kesejahteraan calon anak angkat, melainkan juga demi calon orangtua angkat supaya mendapatkan tunjangan anak dalam daftar gaji, juga hal ini dibenarkan secara legal-formal menurut Peraturan Pemerintah Republik Indonesia Nomor 7 Tahun 1977 tentang Peraturan Gaji Pegawai Negeri Sipil Pasal 16 ayat 2, maka pada bagian ini akan peneliti fokuskan pada implikasi hukum pengangkatan anak yang masih tergolong keluarga, atau bahkan masih merupakan ahli waris misalnya cucu atau keponakan sendiri seperti pada empat kasus yang peneliti jadikan obyek penelitian ini. Analisis implikasi hukum pengangkatan anak dari sisi ini jelas sangat urgen, sebab jika dilihat secara sekilas akan tampak terjadi dualis hukum yang menyangkut hukum waris dan wasiat wajibah terhadap anak angkat.

Selanjutnya, untuk memudahkan analisis tentang implikasi hukum terhadapPergeseran Orientasi Adopsi Anak yang Dilakukan oleh Pegawai Negeri Sipil (PNS) di Kabupaten Lombok Tengah, peneliti mengambil satu sampel kasus pengangkatan anak dimana calon anak angkat tidak lain merupakan cucu calon orang tua angkat. Misalnya Penetapan Pengadilan Agama di Lombok Tengah Nomor 0403/Pdt.P/2014/PA.PRA. Penetapan ini adalah penetapan Pengadilan Agama Praya (tingkat pertama) dalam perkarapengangkatan anak yang dimohonkan oleh Pemohon I atas nama Baiq Haryani binti Lalu Moh. Sidik, umur 47tahun, agama Islam, pendidikan S1, pekerjaan PNS (Guru SDN Bagek Polak), bertempat tinggal di Dusun Tenaru, Desa Darek, Kecamatan Praya Barat Daya, Kabupaten Lombok Tengah, selanjutnya disebut sebagai Pemohon I; dan Pemohon II atas nama Lalu Samidah bin Mamiq Lusin, umur 65 tahun, agama Islam, pekerjaan Wiraswasta, pekerjaan PNS, bertempat tinggal di Dusun Tenaru, Desa Darek, Kecamatan Praya Barat Daya, Kabupaten Lombok Tengah, selanjutnya disebut sebagai Pemohon II;

Berdasarkan Duduk Perkara yang termuat dalam penetapan tersebut diketahui bahwa Pemohon telah mengajukan perkaranya tertanggal 23 September 2014 yang telah terdaftar di Kepaniteraan Pengadilan Agama Praya Nomor: 0403/Pdt.P/2014/ PA.PRA tanggal 23 September 2014 mengemukakan hal-hal yang pada pokoknya sebagai berikut: Bahwa Pemohon bermaksud mengangkat seorang anak yang bernama Letra Junita Ningrum binti Sutrisna Ramdani (Perempuan) umur dua puluh tujuh (27) bulan dengan alasanmengajukan permohonan pengangkatan anak, antara lain bahwa pemohon I telah melangsungkan pernikahan pada tanggal 16 Nopember 1997 dengan Pemohon II menurut agama Islam di hadapan Pegawai Pencatat Nikah Kantor Urusan Agama Kecamatan Praya Barat Daya di Desa Darek, Kecamatan Praya Barat Daya, Kabupaten Lombok Tengah, sebagaimana Kutipan Akta Nikah 
Nomor: 158.01.IX.2006; Pemohon pernah menikah dengan laki-laki lain dan telah dikaruniai tiga (3) orang anak, dua orang telah berkeluarga, satu orang sudah, satu orang masih mengikuti mengikuti pendidikan di Universitas Yogyakarta dan selama pernikahan Pemohon I dan II tidak dikaruniai anak, sehingga para Pemohon merasa kesepian dan membutuhkan kehadiran seorang anak; Pemohon I dan II telah hidup rukun sebagaimana layaknya suami dan isteri dan tidak pernah ada masalah serta anak yang diangkat para Pemohon angkat sejak lahir telah dipelihara oleh Pemohon; Adapun orang tua kandung calon anak angkat tidak mampu untuk merawat dan mendidik anak tersebut; Selain itu, orangtua kandung calon anak angkat tidak keberatan dan setuju Pemohon mengambil anak tersebut sebagai anak angkat demi kepentingan pemeliharaan dan pendidikan yang baik. Pemohon, selain sebagai PNS juga memiliki penghasilan lain sehingga mampu untuk mengurus anak tersebut dan keperluan pendidikannya. Alasan utama Pemohon mengangkat 1 orang anak terseut adalah untuk terpeliharanya kehidupan, kesejahteraan dan pendidikan anak tersebut dan Pemohon memiliki penghasilan yang cukup untuk merawat anak tersebut.

Atas dasar alasan atau dalil-dalil sebagaimana sudah ditegaskan di atas, maka Pemohon memohon kepada Ketua Pengadilan Agama/Majelis Hakim kiranya dapat mempertimbangkan permohonan Pemohon tersebut dengan memberikan putusan primaer: 1) Mengabulkan permohonan Pemohon; 2) Menyatakan sah pengangkatan anak yang dilakukan oleh Pemohon I (Baiq Haryani binti Lalu Muh. Sidik) dan Pemohon II (Lalu Samidah bin Mamiq Lusin) Desa Darek, Kecamatan Praya Barat Daya, Kabupaten Lombok Tengah terhadap anak yang bernama Letra Junita Ningrum binti Sutrisna Ramdani (perempuan, umur dua puluh tujuh bulan; 3) Membebankan biaya perkara kepada Pemohon sesuai hukum yang berlaku.

Disamping hal di atas dalam duduk perkara ini juga disebutkan bahwa pada hari sidang yang telah ditetapkan, para pemohon telah menghadap sendiri di persidangan dan Majelis Hakim telah memberikan nasehat dan penjelasan sedemikian rupa kepada para pemohon tentang pengertian dan akibat-akibat hukum pengangkatan anak, menurut hukum Islam serta besarnya tanggung jawab orang tua angkat terhadap anak angkatnya, mengingat anak yang diangkat tersebut masih CUCUPemohon I dan Pemohon II sendiri yang jika ada suatu hal Pemohon ikut bertanggung jawab, akan tetapi Pemohon tetap pada maksudnya.

Selanjutnya dibacakan surat permohonan para pemohon yang isinya tetap dipertahankan oleh para pemohon, bahwa: Untuk meneguhkan dalil-dalil permohonannya,PemohonIdanIImengajukan alat-alatbuktisuratberupa:1) Fotocopy Kartu Tanda Penduduk (KTP) atas nama Pemohon I NIK 52.02.05.7114.7011.7000.3 yang dikeluarkan oleh Kantor Camat Praya Barat Daya Kabupaten Lombok Tengah 
tanggal 06 Juli 2012, yang telah bermaterai cukup, dan telah dicocokkan dengan aslinya dan ternyata cocok, selanjutnya diberi tanda P.1.; 2) Foto Copy, Kartu Tanda Penduduk (KTP) atas nama Pemohon II NIK 52.02.11.0107490104 yang dikeluarkan oleh Kantor Camat Praya Barat Daya Kabupaten Lombok Tengah tanggal 17 Maret 2012, yang telah bermaterai cukup, dan telah dicocokkan dengan aslinya dan ternyata cocok, selanjutnya diberi tanda P.2; 3) Foto Copy Kutipan Akta Nikah atas anama Pemohon I dan II Nomor: 158/01/IX/2006 yang dikeluarkan oleh Kantor Urusan Agama Kecamatan Praya Barat Daya Kabupaten Lombok Tengah dan telah dicocokkan dengan aslinya dan ternyata cocok, selanjutnya diberi tanda P.3; 4) Foto Copy Kartu Keluarga atas nama Lalu Samidah Nomor 5202110902081747 tanggal 04 Januari 2014 yang dikeluarkan oleh Kantor Catatan Sipil dan Kependudukan Kabupaten Lombok Tengah, yang telah bermaterai cukup, dan telah dicocokkan dengan aslinya dan ternyata cocok, selanjutnya diberi tanda P.4; 5) Foto Copy Kartu Tanda Penduduk (KTP) atas nama Baiq Tri Marlinda (Ibu Anak yang diangkat) NIK 5202117008940001 yang dikeluarkan oleh Kantor Camat Praya Barat Daya Kabupaten Lombok Tengah tanggal 02 Juli 2012, yang telah bermaterai cukup, dan telah dicocokkan dengan aslinya dan ternyata cocok, selanjutnya diberi tanda P.4; 6) Kartu Tanda Penduduk (KTP) atas nama Sutrisna Ramdani (Ayah Anak yang diangkat) NIK 5202012303930001 yang dikeluarkan oleh Kantor Camat Praya Barat Daya Kabupaten Lombok Tengah tanggal 04 Juli 2012, yang telah bermaterai cukup, dan telah dicocokkan dengan aslinya dan ternyata cocok, selanjutnya diberi tanda P.5; 7) Foto Copy Kutipan Akta Nikah atas nama Sutrisna Ramdani danBaiq Tri Marlinda Nomor: 34/34/I/2013 yang dikeluarkan oleh Kantor Urusan Agama Kecamatan Praya Barat Daya Kabupaten Lombok Tengah tanggal 20 Desember 2011 dan telah dicocokkan dengan aslinya dan ternyata cocok, selanjutnya diberi tanda P.6; 8) Foto Copy Akte Kelahiran atas nama Letra Junita Ningrum Nomor 5202115006120002, tanggal 24 Januari 2014 yang dikeluarkan oleh Kantor Catatan Sipil dan Kependudukan Kabupaten Lombok Tengah, yang telah bermaterai cukup, dan telah dicocokkan dengan aslinya dan ternyata cocok, selanjutnya diberi tanda P.6; 9) Kartu Keluarga atas nama Sutrisna Ramdani Nomor 5202113005130002 tanggal 10 Januari 2014 yang dikeluarkan oleh Kepala Dinas Catatan Sipil dan Kependudukan Kabupaten Lombok Tengahyang telah bermaterai cukup, dan telah dicocokkan dengan aslinya dan ternyata cocok, selanjutnya diberi tanda P.9; 10) Foto Copy Surat kenaikan Pangkat Pemohon I tertanggal 21 Desember 2011, yang dikeluarkan oleh Gubernur Nusa Tenggara Barat, Kota Mataram, telah bermaterai cukup, dan telah dicocokkan dengan aslinya dan ternyata cocok, selanjutnya diberi kode tanda bukti P.10; 11) Surat Petikan pembayaran Gaji atas nama Baiq Haryani (Pemohon 
I) tanggal 15 September 2014 yang dikeluarkan oleh Kepala UPT Dinas Pendidikan Pemuda dan Olahraga, Kecamatan Praya Barat DayaKabupaten Lombok Tengahyang telah bermaterai cukup, dan telah dicocokkan dengan aslinya dan ternyata cocok, selanjutnya diberi tanda P.11; dan 12) Surat Keterangan Penghasilan Pemohon II Nomor 145/214/D.D/2014, tanggal 04 September 2014, yang dikeluarkan oleh Kepala Desa Mangkung, Kecamatan Praya Barat DayaKabupaten Lombok Tengah, selanjutnya diberi tanda bukti P.12.

Selain bukti-bukti surat tersebut para pemohon juga mengajukan 2 orang saksi, yaitu saksi pertama bernama Lalu Arifin Supandi bin Panun, umur 44 tahun, agama Islam, pekerjaan Dagang, bertempat tinggal di Lingkungan Prapen, Kelurahan Prapen, Kecamatan Praya, Kabupaten Lombok Tengah, dan Lalu Ramdani Hidayat bin Lalu Samidah,umur 33 tahun, agama Islam, pekerjaan Honorer pada Kantor Desa Darek, Bertempat tinggal di Dusun Bual, Desa Darek, Kecamatan Praya Barat Daya,Kabupaten Lombok Tengah. Di bawah sumpahnya, kedua saksi memberikan keterangan bahwa pada pokoknya sebagai berikut: 1) Saksi kenal dengan Pemohon I Baiq Haryani dan Pemohon II bernama Lalu Samidah; 2) saksi tahu Pemohon I dan II adalah suami isteri; 3) Pemohon I dan II telah dikarunia tiga (3) orang anak, akan tetapi 2 orang anak telah menikah dan yang 1 orang anak masih mengikuti pendidikan; 4) saksi kenal dengan Pemohon I dan II dari sejak pernikahan orang tua anak yang akan diangkat; 5) Saksi kenal dengan anak yang akan diangkat oleh Pemohon I dan II bernama Letra Junita Ningrum; 6) Saksi tahu tujuan Pemohon I dan II datang ke Pengadilan Agama yaitu para Pemohon mau mengangkat anak; 7) Bahwa anak yang mau diangkat oleh para pemohon adalah cucunya Anak dari Baiq Tri Marlinda; Para pemohon adalah orang yang cukup mampu apabila mengangkat anak; 8) sepengetahuan saksi pekerjaan Pemohon I adalah PNS (guru SD); 9) Saksi tidak tahu jumlah gaji Pemohon; 10) Para pemohon mampu untuk memenuhi segala kebutuhan anak-anaknya termasuk anak yang akan diangkat Para Pemohon; 11) Para pemohon meruapakan orang yang baik di kalangan masyarakat dan keluarga; 12) Tidak ada yang merasa keberatan dari Pihak Para Pemohon apabila mengangkat anak; 13) Sebab orang tua anak yang diangkat mau menyerahkan anaknya untuk diambil menjadi anak angkat oleh Para Pemohon karena orang tua anak yang diangkat belum mempunyai pekerjaan tetap dan yakin anaknya lebih terjamin kehidupannya teruatama pendidikannya bila diangkat oleh Para Pemohon.

Selain itu, Pemohon juga menghadirkan orang tua dari anak Letra Junita Ningrum dan memberi keterangan bahwa dirinya kurang mampuuntuk memelihara dan merawat anak karena ayah dari calon anak yang diangkat tidak memiliki pekerjaan tetap sementara Ibu kandung dan Bapak Kandung anak yang diangkat kurang mampu 
memenuhi kebutuha anak terutama biaya pendidikannya, dan karena itu bersedia menyerahkan anaknya kepada Pemohon I dan Pemohon II karena ia percaya para pemohon akan mampu untuk memelihara dan merawat anaknya layaknya anak kandung sendiri dan tidak memutuskan hubungan dengan bapak dan ibu kandung si anak; serta Pemohon tidak mengajukan sesuatu apapun kecuali mohon penetapan.

Sebagai pertimbangan hukum, maka sesuai fakta persidangan bahwa pada hari sidang yang telah ditentukan para pemohon telah hadir di persidangan dan pada pokoknya para pemohon memohon agar Pengadilan Agama memberikan penetapan tentang pengangkatan anak untuk mendapatkan kepastian hukum sahnya pengangkatan anak yang dilakukan Pemohon I dan Pemohon II berdasarkan hukum Islam terhadap seorang anak perempuan bernamaLetra Junita Ningrum, perempuan, umur dua puluh tujuh bulan.

Berdasarkan ketentuan penjelasan Pasal 49 huruf (a) angka 20 Undang-Undang Nomor 3 Tahun 2006 tentang Perubahan atas Undang-Undang Nomor 7 Tahun 1989 tentang Peradilan Agama bahwa Peradilan Agama berwenang mengadili dan menyelesaikan perkara tentang penetapan asal usul anak dan penetapan pengangkatan anak berdasarkan hukum Islam; Selain itu, untuk menguatkan dalil permohonannya, Pemohon pun telah mengajukan 12alat-alat bukti surat (P.1 sampai P.12) maupun saksi-saksi, dan Majelis Hakim mendapatkan fakta-fakta yang semuanya bersesuaian dan cocok sebagaimana alat-alat bukti dan saksi yang disampaikan itu, maka dengan demikian, berdasarkan fakta-fakta hukum tersebut di atas Majelis Hakim berpendapat bahwa oleh karena orang tua kandung dari anak bernama Letra Junita Ningrum, perempuan, umur dua puluh tujuh bulan, tidak mempunyai pekerjaan tetap, maka secara psikologis maupun secara ekonomi anak tersebut membutuhkan biaya hidup, biaya pendidikan yang lebih layak, dan akrena alasan tersebut orang tuan anak secara sukarela menyerahkan anaknya untuk diangkat dan dirawat oleh orang lain yaitu Pemohon I dan Pemohon II.

Berdasarkan fakta-fakta hukum yang terungkap itu pula Majelis Hakim berpendapat bahwa Pemohon I dan Pemohon II mampu memelihara anak tersebut karena para Pemohon berpenghasilan lebih dari cukup. Selain itu, anak yang akan diangkat tidak lain adalah cucu dari Para Pemohon sendiri. Lagipula orang tua kandung dari anak tersebut (Sutrisna Ramdani dan Baiq Tri Marlinda) tidak keberatan jika beralih pemeliharaannya dari orang tua kandungnya kepada para Pemohon.

Menurut aturan dalam Pasal 171 huruf (h) Kompilasi Hukum Islam bahwa yang dimaksud anak angkat adalah anak yang dalam pemeliharaannya untuk hidupnya sehari-hari, biaya pendidikan dan sebagainya beralih tanggungjawabnya dari orang tua asal kepada orang tua angkatnya berdasarkan Penetapan Pengadilan Agama. 
Berdasarkan Pasal tersebut di atas, Majlis bahwa permohonan pengangkatan anak berdasarkan hukum Islam bukan berarti adopsi karena tidak merubah status nasab anak, yang terjadi adalah peralihan tanggung jawab pemeliharaan, pendidikan dan sebagainya dari orang tua asal kepada orang tua angkat. Begitu juga pengangkatan anak dalam pandangan hukum Islam tidak memtus hubungan darah antara anak dengan orang tua asalnya, sehingga jika anak angkat perempuan kelak jika hendak menikah maka yang menjadi wali nikahnya adalah bapak asalnya. Maka Majelis sependapat dengan doktrin fiqh Islam yang termuat dalam kitab "al-fiqh al-Islamy wa adillatuhu" dan diambil alih menjadi pertimbangan Majelis yang Artinya: "Barang siapa yang mengangkat anak baik anak laqith maupun anak yang majbul nasabnya dengan tidak bermaksud menjadikan anak asalnya, maka anak tersebut bukan menjadi anak. bakiki (anak asal), sebingga tidak berlaku bukum waris dan mubrim, akan tetapi Islam tidak melarang (babkan menganjurkan) agar punya kepedulian terhadap pemeliharaan dan pendidikan anak laqith";

Berdasarkan pertimbangan-pertimbangan tersebut diatas dan dihubungkan dengan peraturan perundang-undangan hukum yang berlaku serta didasarkan pula dengan doktrin fiqh Islam, maka Majelis berpendapat bahwa cukup beralasan jikalau anak bernama Letra Junita Ningrum, perempuan, umur dua puluh tujuh bulan beralih pemeliharaannya dari orang tua kandungnya kepada Pemohon I dan Pemohon II sehingga dengan pertimbangan tersebut pula patut kiranya permohonan PemohonI dan Pemohon II untuk mengangkat Letra Junita Ningrum, perempuan, umur dua puluh tujuh bulan dapat dikabulkan;

Berdasarkan pasal 89 ayat (1) Undang-undang Nomor 7 Tahun 1989, yang telah diubah dan ditambang dengan Undang-undang Nomor 3 tahun 2006 serta perubahan kedua dengan Undang-undang Nomor 50 tahun 2009, biaya perkara dibebankan kepada Pemohon I dan Pemohon II;

Mengingat segala peraturan perundang-undangan yang berlaku dan hukum Islam yang bersangkutan, maka Majelis menetapkan: 1) Mengabulkan permohonan Pemohon I dan Pemohon II; 2) Menyatakan sah pengangkatan anak yang dilakukan oleh Pemohon I (Baiq Haryani binti Lalu Moh. Sidik) dan Pemohon II (Sri Lalu Samidah bin Mamiq Lusin) beralamat di Dusun Tenaru, Desa Darek, Kecamatan Praya Barat Daya, Kabupaten Lombok Tengah terhadap anak yang bernama Letra Junita Ningrum, perempuan, umur dua puluh tujuh bulan; 3) Membebankan kepada Pemohon untuk membayar biaya perkara sebesar Rp. 251.000,- (dua ratus lima puluh satu ribu rupiah);

1. Dasar dan Implikasi Hukum Pengangkatan Cucu sebagai Anak Angkat 
Jika melihat pada temuan penelitian bahwa Letra Junita Ningrum, perempuan, umur dua puluh tujuh bulan, anak dari pasangan suami isteri bernama Sutrisna Ramdani dan Baiq Tri Marlinda, yang dalam penetapan Pengadilan Agama di atas diangkat oleh para pemohon sebagai anak angkat, adalah cucu mereka sendiri (para pemohon). Oleh karena itu, bagaimana implikasi hukum pengangkatan cucu yang notabene merupakan anak dari anak kandung pemohon sendiri?

Dalam analisis Hotnidah Nasution ${ }^{25}$, berdasarkan pasal 2 Peraturan Menteri Sosial Republik Indonesia Nomor 110/Huk/2009 tentang Persyaratan Pengangkatan Anak menyebutkan bahwa prinsip pengangkatan anak meliputi: (1) Pengangkatan anak hanya dapat dilakukan untuk kepentingan terbaik bagi anak serta dilakukan berdasarkan adat kebiasaan setempat dan ketentuan peraturan perundang-undangan yang berlaku. (2) Pengangkatan anak tidak memutuskan hubungan darah antara anak yang diangkat dengan orang tua kandungnya. (3) Calon orang tua angkat harus seagama dengan agama yang dianut oleh calon anak angkat. (4) Dalam hal asal usul anak tidak diketahui maka agama anak disesuaikan dengan agama mayoritas penduduk tempat ditemukannya anak tersebut. (4) Pengangkatan anak warga negara Indonesia oleh warga negara asing hanya dapat dilakukan sebagai upaya terakhir. Selanjutnya dalam ayat 2 dari pasal tersebut disebutkan bahwa "Selain prinsip sebagaimana dimaksud pada ayat (1) orang tua angkat wajib memberitahukan kepada anak angkatnya mengenai asal usulnya dan orang tua kandungnya dengan memperhatikan kesiapan mental anak".

Senada dengan itu, selanjutnya, pasal 4 Peraturan Menteri Sosial Republik Indonesia Nomor 110/Huk/2009 menyatakan bahwa syarat material calon anak yang dapat diangkat meliputi: pertama, anak yang belum berusia 18 tahun akan tetapi dalam pasal 6 terkait dengan usia ini dibagi dalam 3 kategori yang meliputi: (1) Anak belum berusia 6 tahun merupakan prioritas utama, yaitu anak yang mengalami keterlantaran, baik anak yang berada dalam situasi mendesak maupun anak yang memerlukan perlindungan khusus. (2) Anak berusia 6 tahun sampai dengan belum berusia 12 tahun sepanjang ada alasan mendesak berdasarkan laporan sosial yaitu anak terlantar yang berada dalam situasi darurat. (3) Anak berusia 12 tahun sampai dengan belum berusia 18 tahun yaitu anak terlantar yang memerlukan perlindungan khusus. Kedua, merupakan anak terlantar atau diterlantarkan. Ketiga, berada dalam asuhan keluarga atau dalam Lembaga Pengasuhan Anak. Keempat, memerlukan perlindungan khusus.

25 Hotnidah Nasution, "Penetapan Cucu sebagai Anak Angkat dan Implikasinya Terhadap Masalah Waris, Abkam, Vol. XIV, No. 1, Januari 2014, hlm. 76-77. 
Selanjutnya dalam pasal 5 dari peraturan tersebut disebutkan bahwa permohonan pengangkatan anak harus melampirkan persyaratan administratif calon anak angkat yang meliputi: (1) Copy KTP orang tua kandung/wali yang sah/kerabat calon anak angkat, (2) Copy kartu keluarga orang tua calon anak angkat, dan (3) Kutipan akta kelahiran calon anak angkat.

Terkait dengan calon orang tua angkat dalam pasal 7 Peraturan Menteri Sosial Republik Indonesia Nomor 110/Huk/2009 disyaratkan: (1) Sehat jasmani dan rohani, (2) Berumur paling rendah 30 tahun dan paling tinggi 55 tahun ${ }^{26}$ (3) Beragama sama dengan agama calon anak angkat, (4) Berkelakuan baik dan tidak pernah dihukum karena melakukan tindak kejahatan, (5) Berstatus menikah secara sah paling singkat 5 tahun, (6) Tidak merupakan pasangan sejenis, (7) Tidak atau belum mempunyai anak atau hanya memiliki satu orang anak, (8) Dalam keadaan mampu secara ekonomi dan sosial, (9) Memperoleh persetujuan anak ${ }^{27}$ dan izin tertulis dari orang tua atau wali anak, (10) Membuat pernyataan tertulis bahwa pengangkatan anak adalah demi kepentingan terbaik bagi anak serta kesejahteraan dan perlindungan anak, (11) Adanya laporan sosial dari pekerja sosial setempat, (12) Telah mengasuh calon anak angkat paling singkat 6 bulan sejak izin pengasuhan diberikan, dan (13) Memperoleh izin Menteri atau Kepala Instansi Sosial Propinsi.

Jika melihat Peraturan Menteri Sosial Republik Indonesia di atas, maka, menurut Hotnidah Nasution, tidak ada halangan bagi seorang kakek dan nenek untuk mengangkat cucu kandungnya sebagai anak angkat. ${ }^{28}$ Merujuk pada peraturan di atas, pengangkatan anak oleh para pihak dalam penetapan ini tidak bertentangan dengan peraturan tersebut karena baik kakek dan nenek sebagai orang tua angkat dan cucu sebagai anak angkat sama-sama beragama Islam, umur anak angkat belum mencapai usia 18 tahun (Letra Junita Ningrum baru berumur 27 bulan yang berdasarkanpasal 4 Peraturan Menteri Sosial Republik Indonesia Nomor 110/Huk/2009: "Anak belum berusia 6 tahun merupakan prioritas utama,..”) dan umur orang tua angkat belum mencapai 55 tahun.

Hanya saja dalam peraturan di atas disebutkan bahwa pengangkatan anak dilakukan bagi keluarga yang tidak memiliki anak atau hanya memiliki satu anak saja, tetapi pada penetapan di atas pada faktanya disebutkan bahwa para pihak telah memiliki tiga (3) orang anak, dua dari mereka telah telah berkeluarga, satu orang sudah dewasa tapi belum menikah dansaat ini masih mengikuti mengikuti pendidikan

26 Umur calon orang tua angkat sebagaimana dimaksud pada ayat (1) huruf b yaitu perhitungan umur calon orang tua angkat pada saat mengajukan permohonan pengangkatan anak.

27 Persetujuan tertulis dari calon anak angkat sebagaimana dimaksud pada ayat (1) huruf i disesuaikan dengan tingkat kematangan jiwa dari calon anak angkat

28 Hotnidah Nasution, "Penetapan Cucu ..., hlm. 76-77. 
di Universitas Yogyakarta dan selama pernikahan Pemohon I dan II tidak dikaruniai anak, sehingga para Pemohon merasa kesepian dan membutuhkan kehadiran seorang anak. Dengan kata lain, para Pemohon tidak memiliki anak yang tinggal bersama mereka saat ini dan menjadi tanggungjawab mereka.Hal itu dimungkinkan dan Majelis Hakim berpendapat tidak menyalahi aturan pasal 7 Peraturan Menteri Sosial Republik Indonesia Nomor 110/Huk/2009 huruf g yang berbunyi “Tidak atau belum mempunyai anak atau hanya memiliki satu orang anak" karena bisa jadi para pihak disamakan pada saat pengangkatan anak hanya memiliki satu anak karena pada faktanya disebutkan para pihak tidak memiliki anak yang menjadi tanggung jawab mereka karena tiga anak telah beranjak dewasa.

Dalam penetapan tersebut tidak disebutkan berapa usia 3 anak tersebut, padahal seperti dimaklumi bahwa usia dewasa menurut peraturan yang ada juga masih berbeda-beda. Burgelijk Wetboek (BW) misalnya menganggap seseorang dewasa kalau telah berusia genap 21 tahun atau sudah menikah, hukum Islam umur 15 tahun atau sudah mimpi basah bagi laki-laki dan menstruasi bagi perempuan, UU Nomor 23 Tahun 2002 tentang Perlindungan Anak menyebutkan 18 tahun, UU Nomor 2 Tahun 2008 tentang Partai Politik menyebutkan 17 tahun atau sudah/pernah kawin, UU nomor 10 Tahun 2008 tentang Pemilihan Umum menetapkan 17 tahun atau sudah/pernah kawin, UU Nomor 11 Tahun 2012 tentang Sistem Peradilan Pidana Anak menetapkan 18 tahun dan UU Nomor 4 Tahun 1979 tentang Kesejahteraan Anak menetapkan 21 tahun.

Undang-undang secara umum mengatur usia dewasa 21 tahun sedangkan undang-undang yang lebih khusus mengatur usia dewasa di bawah usia 21 tahun. Oleh karena itu Mahkamah Agung menyepakati usia dewasa masing-masing diberlakukan undang-undang yang secara khusus maupun secara umum mengatur tentang usia dewasa tersebut tergantung dalam bentuk apa dan bagaimana kasusnya sesuai dengan pengertian dewasa yang diatur dalam masing-masing undang-undang sektoral dimaksud. ${ }^{29}$

2. Kewajiban Kakek dan Nenek kepada Cucu

Dalam penetapan di atas disebutkan alasan para pemohon (kakek dan nenek) untuk mengangkat calon anak angkat (cucu) untuk menjadi anak angkat adalah demi kelangsunganpendidikan dan kesejahteraan anak angkat (cucu) karena kedua orang tua kandung si cucu calon anak angkat tidak mampu untuk merawat dan mendidik anak tersebut. Selain itu, orangtua kandung calon anak angkat tidak keberatan dan

29 Atja Sondjaj, "Beberapa Permasalahan Hukum”, dalam http://www.mahkamahagung.go.id, diunduh pada tanggal 7 Agustus 2015. 
setuju Pemohon mengambil anak tersebut sebagai anak angkat demi kepentingan pemeliharaan dan pendidikan yang baik.

Pada pembahasan sebelumnya telah dijelaskan bahwa tidak ada halangan bagi kakek dan nenek untuk mengangkat cucunya sebagai anak angkat sepanjang pengangkatan itu dilakukan menurut peraturan yang berlaku. Salah satu prinsip pengangkatan anak adalah untuk kepentingan terbaik bagi anak ${ }^{30}$. Hal ini terkait dengan tanggung jawab nafkah demi keberlangsungan kesejahteraan anak. Fakta dalam kasus ini adalah kakek dan nenek dari pihak ayah merupakan orang yang ingin mengangkatnya sebagai anak. Maka tentunya perlu dikaji apakah kakek dan nenek dari pihak ayah yang mampu secara ekonomi bertanggung jawab terhadap nafkah cucu tanpa harus mengangkatnya sebagai anak angkat.

Jika ayah masih mampu bekerja dan termasuk kaya, menurut mayoritas ulama, maka ia sendiri berkewajiban menanggung nafkah anak-anaknya tanpa dibantu oleh orang lain berdasarkan firman Allah Swt. yang artinya "....dan kewajiban ayah menanggung nafkah dan pakaian mereka dengan cara yang laik...(Q.s. al-Baqarah [2]: 233)".31

Adapun jika ayah sudah tidak ada atau ada tetapi miskin, lemah atau tidak mampu bekerja, sakit, sudah lanjut usia atau sejenisnya maka menurut pendapat Hanafiyyah tanggung jawab nafkahnya dilimpahkan kepada keluarga jalur ke atas yang masih ada, baik laki-laki maupun perempuan jika mampu. Artinya, kakek berkewajiban memberi nafkah kepada cucunya jikaia mampu atau ibu terhadap anaknya jika ia mampu.

Kewajiban kakek dan ibu memberi nafkah kepada cucu sesuai bagian warisan mereka. Artinya bagian ibu $1 / 3$ dan bagian kakek 2/3. Jika misalnya si cucu memiliki dua orang nenek yaitu ibunya ibu dan ibunya ayah maka kedua nenek tersebut bagiannya $1 / 6$ sedangkan untuk kakek sesuai dengan bagian warisannya. Berbeda dengan Imâm Mâlik, menurutnya nafkah anak yang wajib hanyalah anak yang langsung saja, anaknya anak (cucu) tidak termasuk di dalamnya. Pendapatnya ini didasarkan pada zahir Q.s. al-Baqarah [2]: 233 yaitu $^{32}$

"Dan ibu-ibu hendaklah menyusui anak-anaknya selama dua tahun penub bagi yang ingin menyusui secara sempurna. Dan kewajiban ayah menanggung nafkah dan pakaian mereka dengan cara yang patut...”.

30 Pasal 2 ayat 1 Peraturan Menteri Sosial Republik Indonesia Nomor 110/Huk/2009 tentang Persyaratan Pengangkatan Anak, Pasal 39 ayat (1), (2) dan ayat (3) UU No. 23 Tahun 2002.

31 Wahbah al-Zuhaylî, "Al-Fiqh al-Islâmî Wa Adillatuhu", diterjemahkan oleh Tim Penerjemah Gema Insani, (Jakarta: Gema Insani Press, 2011), hlm. 140.

32 Ibid., hlm. 137. 
Ulama Syâfi'iyyah berpendapat jika anak tidak memiliki ayah atau ada tetapi lemah dan tidak mampu bekerja maka nafkah anak tersebut ditanggung oleh ibunya. Hal ini didasarkan pada firman Allah Swt. dalam Q.s. al-Baqarah [2]: 233 yang artinya "...janganlah seorang ibu menderita karena anaknya dan jangan pula seorang ayah (menderita) karena anaknya...”. Jika nafkah anak itu wajib atas ayah secara zahir maka nafkah itu wajib juga atas ibu dan ia juga wajib memberi nafkah untuk cucu karena nenek itu hukumnya seperti ibu sedangkan kakek sama seperti ayah dalam hal mengurus anak. Dalam pendapat yang lebih sahih dinyatakan bahwa jika masih ada ibu dan kakek dari pihak ayah maka nafkahnya ditanggung oleh kakek. Jika kakek dan nenek si anak masih lengkap maka nafkahnya ditanggung oleh yang paling dekat. ${ }^{33}$

Ulama Hanâbilah berpendapat bahwa jika si anak sudah tidak memiliki ayah maka nafkahnya wajib ditanggung oleh setiap ahli waris sesuai dengan kadar bagian warisan masing-masing. Artinya urutan tanggungan nafkah si anak disesuaikan dengan urutan waris. Misalnya jika si anak hanya memiliki ibu dan kakek maka ibu memberinya $1 / 3$ nafkah sedangkan kakek memberinya $2 / 3$ nafkah karena keduanya termasuk ahli waris. Jika si anak hanya memiliki seorang nenek dan saudara laki-laki maka tanggungan nafkah nenek $1 / 6$ dan sisanya ditanggung oleh saudara lelaki karena dalam konteks waris nenek mendapat 1/6 maka dalam nafkah pun ia menanggung $1 / 6$ dan saudara laki-laki dalam waris mendapat asabat atau sisa maka dalam nafkah ia menanggung sisanya. Jika si anak hanya memiliki kakek dan nenek dari ibu maka nafkahnya ditanggung oleh nenek karena dialah yang termasuk ahli waris. Apabila si anak hanya memiliki saudara laki-laki dan kakek maka keduanya menanggung nafkah dengan kadar yang sama banyaknya. ${ }^{34}$

Dari penjelasan di atas dipahami bahwa tanpa dengan pengangkatan anak pun sebagian ulama berpendapat bahwa para pihak dalam penetapan di atas berkewajiban untuk memberi nafkah kepada cucu mereka (yang akan diangkat) karena pada faktanya ayah dan ibunya tidak mampu untuk membiayai anak mereka.

3. Hak Waris Cucu sebagai Anak Angkat dari Orang Tua Angkat (Kakek dan Neneknya)

Perbuatan mengangkat anak bukanlah suatu perbuatan hukum yang bisa terjadi pada suatu saat seperti halnya dengan penyerahan suatu barang, melainkan merupakan suatu rangkaian kejadian hubungan kekeluargaan yang menunjukkan adanya kesungguhan cinta kasih, kerelaan dan kesadaran yang penuh akan segala akibat selanjutnya dari pengangkatan tersebut bagi semua pihak.Dalam Staatsblad 1917disebutkan bahwa akibat hukum dari pengangkatan anak adalah anak tersebut

33 Ibid., hlm. 79 dan 137.

34 Ibid. 
secara hukum memperoleh nama dari bapak angkat, dijadikan sebagai anak yang dilahirkan dari perkawinan orang tua angkat dan menjadi ahli waris orang tua angkat. Dengan demikian, anak angkat berhak mewarisi harta orang tua angkatnya dengan bagian yang sama besarnya dengan anak yang sah. ${ }^{35}$

Hal ini berbeda dengan apa yang diatur dalam Kompilasi Hukum Islam dimana pengangkatan anak dapat menimbulkan akibat hukum untuk saling mendapatkan bagian harta warisan antara anak angkat dan orang tua angkat tetapi tidak seperti anak kandung. Mereka mendapatkan warisan dengan jalan wasiat wajibah, yaitu walaupun secara in concreto tidak menerima wasiat namun secara yuridis dipandang telah menerima wasiat. Hak anak angkat/orang tua angkat untuk saling mendapatkan bagian harta warisan dengan jalan wasiat wajibah juga tertuang dalam pertimbangan hukum pengangkatan anak dari penetapan yang dijadikan sampel bahan penelitian ini misalnya:

“...selanjutnya yang harus diperhatikan sebagai akibat hukum pengangkatan anak tersebut antara lain: (1) Anak angkat tidak dapat menggunakan nama ayah angkatnya (Q.s. al-Ahzâb [33]: 5), (2) Antara anak angkat dan orang tua angkat dan saudara angkatnya tidak mempunyai hubungan darah, oleh karenanya diantara mereka harus menjaga ketentuan mahram dan hukum Islam, (3) Diantara mereka tidak saling mewarisi. Namun demikian, terhadap orang tua angkat yang tidak menerima wasiat diberi wasiat wajibah sebanyak-banyaknya 1/3 dari harta warisan anak angkatnya, sedangkan terhadap anak angkat yang tidak menerima wasiat diberi wasiat wajibah sebanyak-banyaknya $1 / 3$ dari harta warisan orang tua angkatnya (Pasal 209 ayat (1) dan (2) Kompilasi Hukum Islam) dengan ketentuan tidak melebihi bagian ahli waris...". ${ }^{36}$

Jika pertimbangan ini diperhatikan, maka menurut Hotnidah Nsution lebih lanjut, tampaknya Majelis Hakim yang memeriksa permohonan ini tidak mempertimbangkan siapa yang mengajukan permohonan pengangkatan anak dan siapa yang diangkat sebagai anak angkat sehingga membuat pertimbangan yang secara umum terkesan hanya meng-copy paste dari pertimbangan-pertimbangan permohonan pengangkatan anak sebelumnya. ${ }^{37}$ Padahal, menurutnya,secara jelas dalam alasan para

35 Irma Devita Purnama Sari, Kiat-Kiat Cerdas, Mudah dan Bijak Memahami Masalah Hukum Waris, (Bandung: Kaifa, 2012), hlm. 121.

36 Dokumentasi Pertimbangan Hukum dalam Penetapan Pengadilan Agama di Lombok Tengah Nomor 164/ Pdt.P/2013/PA.PRA, hlm. 4,dan 0403/Pdt.P/2014/PA.PRA, hlm. 5.

37 Ini merupakan salah satu ekses negatif SIADPA dimana hakim menggunakan template SIADPA untuk membuat pertimbangan hukum putusan, padahal Badilag telah menghimbau agar hakim tidak menggunakan template SIADPA untuk membuat pertimbangan hukum putusan. Lihat Majalah Peradilan Agama Edisi 1 Mei 2013, dalam www badilag.net, diunduh pada tanggal 9 Agustus 2015. 
pemohon telah disebutkan bahwa calon anak angkat adalah cucu para pemohon dari anak kandung mereka. Fakta tersebut juga dikuatkan dari kesaksian para saksi yang menyebutkan bahwa calon anak angkat adalah cucu para pemohon.

Akibat dari tidak adanya perhatian siapa yang mengangkat dan siapa yang diangkat maka diantara pertimbangannya ada yang bertentangan dengan hukum Islam yaitu bahwa: “... antara anak angkat dengan orang tua angkat dan saudara angkatnya tidak mempunyai hubungan darah, oleh karenanya diantara mereka harus menjaga ketentuan mahram dan hukum Islam serta diantara mereka tidak saling mewarisi ...". Hal ini, dalam kasus ini, tidak berlaku karena antara calon orang tua angkat dan calon anak angkat mempunyai hubungan darah, karena itu mereka adalah mahram dan juga dalam waris kakek dan nenek ada kalanya bisa berkedudukan sebagai ahli waris dari cucu dalam kondisi ahli waris hanya terdiri atas istri, kakek dan nenek atau ahli waris dari cucu hanya istri, kakek, nenek dan saudara.

Secara umum antara anak angkat dan orang tua angkat menimbulkan akibat hukum saling mewarisi melalui wasiat wajibah. Argumentasi para pembuat draf Kompilasi Hukum Islam menerapkan aturan wasiat wajibah kepada pihak-pihak yang beradopsi adalah bahwa hubungan antara anak angkat dan orang tua angkat sedemikian dekat sehingga dapat ditafsirkan oleh pihak-pihak yang beradopsi sebagai sanak saudara dekat (al-agrabun). ${ }^{38}$

Seraya mengutip pendapat Suparman Usman, Hotnidah juga mendefenisikan wasiat wajibah sebagai wasiat yang pelaksanaannya tidak dipengaruhi atau tidak bergantung pada kemauan atau kehendakorang yang meninggal dunia. Wasiat ini tetap dilaksanakan baik diucapkan atau dikehendaki maupun tidak oleh orang yang meninggal dunia. Jadi pelaksanaan wasiat tersebut tidak memerlukan bukti bahwa wasiat tersebut diucapkan, dituliskan atau dikehendaki, tetapi pelaksanaannya didasarkan pada alasan-alasan hukum yang membenarkan bahwa wasiat tersebut harus dilaksanakan. ${ }^{39}$

Para ahli hukum Islam berbeda pendapat dalam menetapkan hukum wasiat wajibah. Jumhur ulama berpendapat bahwa sifatnya hanya dianjurkan bukan wajib dengan tujuan untuk membantu meringankan yang bersangkutan dalam menghadapi kesulitan hidup. Hal ini berbeda dengan Ibn Hazm, Imâm Abû Ja’far Muhammad ibn Jarîr al-Thabarî dan Abû Bakr ibn 'Abd al-'Azîz yang berpendapat bahwa wasiat wajibah hukumnya wajib. Mereka mendasarkan pendapatnya pada Q.s. al-Baqarah [2]: 180. Menurut mereka perintah untuk berwasiat dalam ayat tersebut adalah untuk

38 Asep Saipudin Jahar dkk, Hukum Keluarga, Pidana dan Ekonomi, (Jakarta: Kencana, 2013), hlm. 90.

39 Suparman Usman \& Yusup Somawinata, Fiqih Mawaris (Hukum Kewarisan Islam), (Jakarta: Gaya Media Pratama, 2002), hlm. 163. Baca juga, Hotnidah, "Penetapan Cucu..., hlm. 79. 
para ahli waris yang terhalang mendapatkan warisan. ${ }^{40}$ Menurut Ibn Hazm apabila tidak diadakan wasiat untuk kerabat dekat yang tidak mendapatkan warisan maka hakim harus bertindak sebagai pewaris, yakni memberikan sebagian warisan kepada kerabat yang tidak mendapat warisan sebagai suatu wasiat wajib untuk mereka. ${ }^{41}$

Dalam fikih mawaris selama ini lembaga wasiat wajibah diperuntukkan bagi cucu yang orang tuanya telah meninggal lebih dahulu dari pewaris ${ }^{42}$ dimana sebagian negara Islam telah memasukkannya dalam perundang-undangan, seperti Mesir, Maroko, Suriah dan Tunisia. ${ }^{43}$ Berbeda dengan di Indonesia yang dalam kompilasi Hukum Islam cucu yang orang tuanya telah meninggal lebih dahulu dari pewaris ditampung oleh lembaga ahli waris pengganti. ${ }^{44}$

Ketentuan wasiat wajibah ini diakui keberadaannya dalam hukum positif di Indonesia sebagaimana diatur dalam pasal 209 Kompilasi Hukum Islam yang berbunyi: (1) Harta peninggalan anak angkat dibagi berdasarkan Pasal 176 sampai dengan 193 tersebut di atas, sedangkan terhadap orang tua angkat yang tidak menerima wasiat wajibah diberi wasiat wajibah sebanyak-banyaknya $1 / 3$ dari harta warisan anak angkatnya. (2) Terhadap anak angkat yang tidak menerima wasiat diberi wasiat wajibah sebanyak-banyaknya $1 / 3$ dari harta warisan orang tua angkatnya.

Berdasarkan bunyi pasal 209 Kompilasi Hukum Islam ayat 1 dan 2 di atas dapat dipahami bahwa wasiat wajibah yang dimaksud oleh KHI adalah wasiat yang diwajibkan berdasarkan ketentuan peraturan perundang-undangan yang diperuntukkan bagi anak angkat atau sebaliknya orang tua angkatnya yang tidak diberi wasiat sebelumnya oleh orang tua angkat atau anak angkatnya dengan jumlah maksimal $1 / 3$ dari harta peninggalan. ${ }^{45}$ Artinya dalam Kompilasi Hukum Islam orang tua angkat secara otomatis dianggap telah meninggalkan wasiat (dan karena itu diberi nama wasiat wajibab) maksimal sebanyak $1 / 3$ dari harta yang ditinggalkan untuk anak angkatnya atau sebaliknya anak angkat untuk orang tua angkatnya, dimana harta tersebut dalam sistem pembagiannya diberikan sebelum dilaksanakan pembagian warisan kepada para ahli warisnya (wasiat wajibah harus ditunaikan terlebih dahulu).

Diakuinya anak angkat/orang tua angkat untuk saling mendapatkan bagian harta warisan dari salah satu pihak dengan jalan wasiat wajibah dalam Kompilasi

40 Andi Syamsu Alam \& Fauzan, Hukum Pengangkatan Anak Persfektif Islam, (Jakarta: Kencana Prenada Media Group, 2008), hlm. 80.

41 Muhibbin dan Abdul Wahid, Hukum Kewarisan Islam sebagai Pembaharuan Hukum Positif di Indonesia, (Jakarta: Sinar Grafika, 2009), hlm. 149.

42 Mohammad Daud Ali, Hukum Islam; Pengantar Ilmu Hukumdan Tata Hukum Islam di Indonesia, Jakarta, PT Raja Grapindo Persada , 2004), hlm. 331-332.

43 Ibid.

44 Ibid.

45 Andi Syamsu Alam \& Fauzan, Hukum Pengangkatan Anak.., hlm. 81. 
Hukum Islam (KHI) merupakan salah satu corak lokal hukum kewarisan Islam di Indonesia. ${ }^{46}$ Pemberian hak wasiat wajibah kepada anak/orang tua angkat oleh KHI dilakukan dengan mengadaptasi nilai hukum adat secara terbatas ke dalam hukum Islam karena beralihnya tanggung jawab orang tua asal kepada orang tua angkat mengenai pemeliharaan kehidupan sehari-hari dan biaya pendidikan berdasarkan putusan pengadilan seperti yang disebutkan dalam huruf (h) pasal 171 di ketentuan umum, yaitu "Terhadap anak angkat yang tidak menerima wasiat diberi wasiat wajibah sebanyak-banyaknya sepertiga harta warisan orang tua angkatnya. ${ }^{47}$

Dengan demikian, pada kasus di atas ada wasiat atau tidak ada wasiat maka cucu (anak angkat) diberi wasiat wajibah sebanyak-banyaknya $1 / 3$ dari harta warisan orang tua angkatnya (kakek dan neneknya). Demikian juga sebaliknya, orang tua angkat (kakek dan neneknya) yang tidak menerima wasiat wajibah diberi wasiat wajibah sebanyak-banyaknya $1 / 3$ dari harta warisan anak angkatnya (cucunya).

Oleh karena itu, dalam konteks ini, peneliti sepakat dengan pendapat Hotnidah bahwa mengingat anak dari orang tua angkat di sini berjumlah 3 orang dan faktanya 2 orang telah menikah termasuk ayah dari orang tua yang diangkat cucu dalam kasus ini tentunya perlu juga dipertimbangkan ke depannya bagaimana perasaan anak-anak lain yang berposisi sebagai ahli waris karena akan memperoleh bagian yang secara kuantitatif lebih sedikit dengan adanya wasiat wajibah kepada salah satu keponakan mereka. Selain itu juga perlu dipertimbangkan perasaan dari cucu-cucu yang lain jika salah satu dari cucu diberi harta dari peninggalan orang tua mereka (yang berposisi sebagai anak) atau dari kakek dan nenek mereka (yang berposisi sebagai cucu dari anak-anak yang lain). Oleh karena itu, berdasarkan kekhawatiran semacam ini, maka sebaiknya kakek dan nenek tidak perlu mengangkat cucu mereka menjadi anak angkat apalagi dalam fakta dia telah mempunyai beberapa anak karena hal ini dapat menimbulkan rasa ketidakadilan dan kecemburuan diantara anggota keluarga yang lain.

Jika memang kakek dan nenek adalah orang mampu maka alangkah bijaknya tanpa menjadikannya menjadi anak angkat tetapi dengan suka rela membantunya baik dari segi pemeliharaan kesejahteraan maupun pendidikannya. Dalam fikih, salah satu imam mazhab ${ }^{48}$ berpendapat bahwa jika ayah sudah tidak ada atau ada tetapi miskin atau lemah dan tidak mampu untuk bekerja, sakit, sudah lanjut usia atau sejenisnya maka tanggung jawab nafkahnya dilimpahkan kepada keluarga jalur ke atas yang masih ada, baik laki-laki maupun perempuan jika memang mampu.

46 Dede Ibin, "Pembuktian Keabsahan Anak Angkat/Orang Tua Angkat dalam Penyelesaian Gugatan Warisan (Wasiat Wajibah) di Pengadilan Agama”, dalam Mimbar Hukum No.42 Thn X. 1999, hlm. 26. 
Artinya, kakek dan nenek berkewajiban memberi nafkah kepada cucu jika mereka adalah orang mampu.

Tindakan tidak menjadikan cucu sebagai anak angkat dalam kasus ini menurut hemat penulis lebih didahulukan dalam rangka untuk mencegah dampak negatif seperti disebutkan di atas. Hal ini sesuai dengan kaidah fikih "Dar' al mafasid muqaddam'ala jalbi al-mashalib"'(menolak kemudaratan lebih utama daripada meraih kemaslahatan/menolak kerusakan lebih didahulukan daripada meraih maslahat)". ${ }^{49}$ Artinya, tindakan tidak menjadikan cucu sebagai anak angkat dalam kasus ini harus lebih didahulukan dalam rangka untuk mencegah dampak negatif di kalangan ahli waris yang lain.

Dengan demikian, maka berdasarkan peraturan yang berlaku, dapat disimpulkan bahwa tidak ada halangan bagi seorang kakek dan nenek untuk mengangkat cucu kandungnya sebagai anak angkat. Salah satu prinsip pengangkatan anak yaitu untuk kepentingan terbaik bagi anak. Hal ini berkaitan dengan tanggung jawab nafkah demi keberlangsungan kesejahteraan anak. Jika dihubungkan dengan kasus yang ada dalam penetapan yang peneliti jadikan obyek penelitian ini, maka sesungguhnya tanpa dengan pengangkatan anak pun para pemohon dalam penetapan tersebut berkewajiban untuk memberi nafkah kepada cucu mereka (yang diangkat) karena pada faktanya ayah dan ibunya tidak mampu untuk membiayai anak mereka.

\section{PENUTUP}

Dari deskripsi di atas dapat disimpulkan beberapa hal:

1. Sesuai dengan Ketetapan Pengadilan Agama Praya, dari tahun 2013 sampai dengan tahun 2015, terdapat empat kasus adopsi anak yang yang dilakukan oleh Pegawai Negeri Sipil (PNS) di Kabupaten Lombok Tengah. Penetapan pertama dengan Nomor 0004/Pdt.P/2013/PA.PRA menetapkan pengesahan pengangkatan anak saudara (keponakan) sebagai anak angkat dan Penetapan kedua dengan164/ Pdt.P/2013/PA.PRA mengesahkan pengangkatan cucu sebagai anak angkat. Pada tahun 2014 melalui Ketetapan dengan Nomor 0403/Pdt.P/2014/PA.PRA, Pengadilan Agama Praya Kabupaten Lombok Tengah memutus dan menetapkan satu kasus adopsi cucu sebagai anak angkat yang dilakukan oleh Pegawai Negeri Sipil (PNS). Terakhir, tahun 2015 (setidaknya sampai bulan Oktober berjalan) peneliti menemukan data satu kasus adopsi anak yang diputuskan/ditetapkan

49 A. Djazuli, Kaidah-Kaidah Fikib; Kaidah-Kaidah Hukum Islam dalam Menyelesaikan Masalah-Masalah yang Praktis, (Jakarta: Kencana, 2007), hlm. 29.82. 
oleh Pengadilan Agama Praya, Lombok Tengah, yaitu Ketetapan Nomor 0002/ Pdt.P/2015/PA.PRA dimana anak yang diangkat merupakan anak saudara (keponakan) orang tua angkat.

2. Motif dan tujuan adopsi anak yang dilakukan oleh Pegawai Negeri Sipil (PNS) di Kabupaten Lombok Tengah dapat dibagi ke dalam dua bagian, yaitu motif dari calon orang tua angkat atau pengangkat dan motif dari orang tua kandung calon anak angkat. Adapun alasan dari calon orang tua angkat, antara lain karena: kesepian, tidak mempunyai keturunan dan atas dasar perasaan sosial. Sedangkan motif dari orang tua kandung calon anak angkat, yaitu: faktor ekonomi dan untuk meningkatkan kesejahteraan anak.

3. Bentuk pergeseran orientasi adopsi atau pengangkatan anak yang dilakukan oleh para pegawai negeri sipil di Lombok Tengah tidak hanya dilakukan demi kesejahteraan calon anak angkat, melainkan juga demi calon orangtua angkat supaya mendapatkan tunjangan anak dalam daftar gaji.

4. Implikasi hukum terhadap pergeseran orientasi adopsi atau pengangkatan anak oleh pegawai negeri sipil di Kabupaten Lombok Tengah dapat dibenarkan secara legal-formal. Sebab, menurut Peraturan Pemerintah Republik Indonesia Nomor 7 Tahun 1977 tentang Peraturan Gaji Pegawai Negeri Sipil Pasal 16 ayat 2 yang memuat tunjangan anak sebesar $2 \%$ per anak dari gaji pokok. Namun demikian, tindakan tidak menjadikan keluarga, baik keponakan dan khususnya cucu sebagai anak angkat dalam kasus ini harus lebih didahulukan dalam rangka untuk mencegah dampak negatif di kalangan ahli waris yang lain, meskipun menurut peraturan yang berlaku tidak ada halangan bagi seorang kakek dan nenek untuk mengangkat cucu kandungnya sebagai anak angkat.

\section{DAFTAR PUSTAKA}

A. Djazuli, Kaidah-Kaidah Fikib; Kaidah-Kaidah Hukum Islam dalam Menyelesaikan Masalab-Masalah yang Praktis, (Jakarta: Kencana, 2007).

Abdul Aziz Dahlan (et. al.), Eksiklopedi Hukum Islam, (Jakarta: Ichtiar Baru Van Hoeve, 1996).

Andi Syamsu Alam \& Fauzan, Hukum Pengangkatan Anak Persfektif Islam, (Jakarta: Kencana Prenada Media Group, 2008).

Asep Saipudin Jahar dkk, Hukum Keluarga, Pidana dan Ekonomi, Jakarta: Kencana, 2013). 
Atja Sondjaj, "Beberapa Permasalahan Hukum”, dalamhttp://www.mahkamahagung. go.id, Wahbah al-Zuhaylî, "Al-Fiqh al-Islâmî Wa Adillatuhu", diterjemahkan oleh Tim Penerjemah Gema Insani, (Jakarta: Gema Insani Press, 2011).

Bushar Muhammad, Pokok - pokok Hukum Adat, (Jakarta: Pradnya Paramita, 2006).

Datuk Usman, Diktat Hukum Adat, Dipakai dalam Lingkungan Sendiri pada FHUSU, Medan, tanpa tahun.

Dede Ibin, "Pembuktian Keabsahan Anak Angkat/Orang Tua Angkat dalam Penyelesaian Gugatan Warisan (Wasiat Wajibah) di Pengadilan Agama", dalam Mimbar Hukum No.42 Thn X. 1999.

Djaja S.Meliala, Pengangkatan Anak (Adopsi) di Indonesia, (Bandung: Tarsito, 1982).

Dokumentasi Pertimbangan Hukum dalam Penetapan Pengadilan Agama di Lombok Tengah Nomor 164/Pdt.P/2013/PA.PRA, hlm. 4,dan 0403/Pdt.P/2014/ PA.PRA.

Hotnidah Nasution, "Penetapan Cucu sebagai Anak Angkat dan Implikasinya Terhadap Masalah Waris, Ahkam, Vol. XIV, No. 1, Januari 2014.

Irma Devita Purnama Sari, Kiat-Kiat Cerdas, Mudah dan Bijak. Memahami Masalah Hukum Waris, (Bandung: Kaifa, 2012).

Irma Setyowati Soemitro, Aspek Hukum Perlindungan Anak, (Jakarta: Bumi Aksara, 1990)

Keputusan Menteri Sosial Nomor 40/HUK/KEP/IX/1980 tentang Organisasi Sosial

Majalah Peradilan Agama Edisi 1 Mei 2013, dalam www badilag.net,

Maulana Hasan Wadong, Pengantar Advokasi dan Hukum Perlindungan Anak, (Jakarta: Grasindo, 2000).

Mohammad Daud Ali, Hukum Islam; Pengantar Ilmu Hukumdan Tata Hukum Islam di Indonesia, (Jakarta, PT Raja Grapindo Persada , 2004).

Mohammad Thalib, Analisa Wanita Dalam Bimbingan Islam, (Surabaya: Al-Ikhlas, 1987). Hilman Hadikusuma, Hukum Waris Adat, (Bandung: Alumni, 1983).

Muderis Zaini, Adopsi Suatu Tinjanan Dari Tiga Sistem Hukum, (Jakarta: Sinar Grafika, 1995).

Muhibbin dan Abdul Wahid, Hukum Kewarisan Islam sebagai Pembaharuan Hukum Positif di Indonesia, (Jakarta: Sinar Grafika, 2009). 
Musthofa Sy., Pengangkatan Anak: Kewenangan Pengadilan Agama, (Jakarta: Kencana, 2008).

Shanti Dellyana, Wanita dan Anak Di Mata Hukum, (Yogyakarta: Liberty, 1988).

Sudikno Mertokusumo, Hukum Acara Perdata Indonesia, (Yogyakarta: Liberty , 1988).

Sumadi Suryabrata, Pengembangan Alat Ukur Psikologis, (Yogyakarta: Andi, 2000).

Suparman Usman \& Yusup Somawinata, Fiqih Mawaris (Hukum Kewarisan Islam), (Jakarta: Gaya Media Pratama, 2002).

W.A. Gerungan, Psikologi Sosial Suatu Ringkasan, (Jakarta: Cet. V Eresco, 1977). 